\title{
THE ROLE OF INVESTMENT INCENTIVES IN REGIONAL FDI REALLOCATION: A REGRESSION-DISCONTINUITY APPROACH
}

\author{
Marián Dinga
}
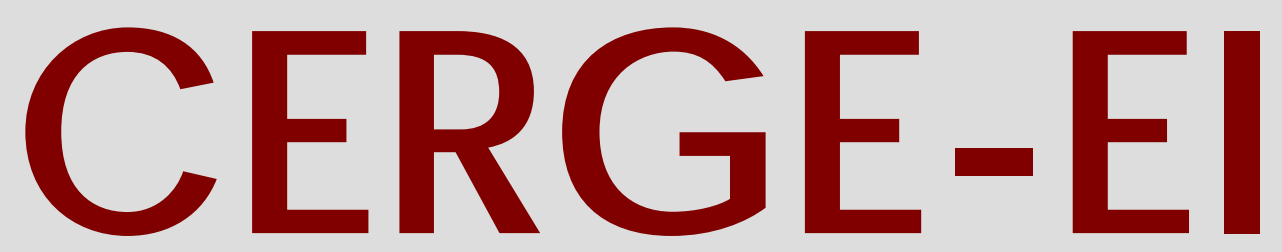

Charles University Centerfor Ec onomic Research and Graduate Education Academy of Sciences of the Czech Republic Ec onomic s Institute 


\section{Working Paper Series 438 (ISSN 1211-3298)}

\section{The Role of Investment Incentives in Regional FDI Reallocation: A Regression-Discontinuity Approach}

Marián Dinga

CERGE-EI

Prague, April 2011 
ISBN 978-80-7343-239-3 (Univerzita Karlova. Centrum pro ekonomický výzkum a doktorské studium)

ISBN 978-80-7344-230-9 (Národohospodářský ústav AV ČR, v.v.i.) 


\title{
The Role of Investment Incentives in Regional FDI Reallocation: A Regression-Discontinuity Approach
}

\author{
Marián Dinga* \\ CERGE-EI, Prague ${ }^{\dagger}$
}

\begin{abstract}
This paper analyzes the causal effect of investment incentives on regional allocation of foreign direct investment (FDI) in the Czech Republic during 2001-2007. Investment incentives institutional setup provided foreign investors with financial incentives depending on the particular district unemployment rate. The identification strategy is based on a regression-discontinuity approach as the scheme design introduces three unemployment thresholds differentiating the amount of the subsidy. The results indicate a positive effect of the investment scheme, but this impact is concentrated only at the lowest available unemployment threshold, increasing annual FDI inflow per capita by 330 euros compared to districts ineligible for the subsidy. However, an impact at higher unemployment thresholds is not found. Attracting FDI into the most distressed regions needs to be complemented with other policy tools and remains to be an important challenge for policymakers. Among other FDI location factors, the share of tertiary educated labor force and wages have significant positive impact on FDI, albeit only during 2001-2004, increasing annual FDI inflow per capita by 25 and 12 euros, respectively.
\end{abstract}

Keywords: foreign direct investment, government expenditures, public incentives, regional development

JEL classification: H53, J08, R12, R38

\footnotetext{
* The author would like to thank Daniel Münich and Štěpán Jurajda for their valuable comments and Randall Filer for his feedback and suggestions. Also, many thanks go to Sarah Peck for editing the manuscript. This research was supported by a grant from the CERGE-EI Foundation under a program of the Global Development Network (RRC VIII-83). All opinions expressed are those of the author and have not been endorsed by CERGE-EI or the GDN. Financial support from the Sasakawa Young Leaders Fellowship Fund of Charles University is gratefully acknowledged. All errors remaining in this text are the responsibility of the author.

${ }^{\dagger}$ CERGE-EI is a joint workplace of the Center for Economic Research and Graduate Education, Charles University, and the Economics Institute of the Academy of Sciences of the Czech Republic. Correspondence address: CERGE-EI, P.O.Box 882, Politických věznuu 7, Prague, Czech Republic. Email: marian.dinga@cerge-ei.cz.
} 


\begin{abstract}
Abstrakt
Tato práce analyzuje dopad investičních pobídek na regionální umístnění přímých zahraničních investic (PZI) v České republice v období 2001-2007. Výše přidělených pobídek byla relativně vyšší v okresech s vysokou nezaměstnaností, čímž systém investičních pobídek lákal investory zejména do regionů nejvíce postižených nezaměstnaností. Identifikační strategie je založena na regresní diskontinuitě, využívajíci vymezení kriterií třema mírami nezaměstnanosti, dle kterých se investor kvalifikuje do různých skupin lišících se výší nárokovatelné pobídky. Výsledky indikují kladný vliv investičních pobídek, nicméně jen pro nejnižší dostupný práh nezaměstnanosti, který zvyšuje roční př́liv PZI na hlavu o 330 eur v porovnání s okresy, které se nekvalifikovaly pro pobídky. Dopad na vyšší prahy nezaměstnanosti nebyl nalezen. Přilákání investičních pobídek do regionů nejvíce postižených nezaměstnaností musí být proto doplněno jinými prostředkami a stále zůstavá důležitou výzvou pro tvůrce politik trhu práce. Mezi ostatními faktory PZI měly v období 2001-2004 významný kladný vliv na PZI podíl vysokoškolsky vzdělané populace a lokální mzdy, když růst o jedno procento zvýšil prŕliv PZI na hlavu o 25, resp. 12 eur. V pozdějších letech tento vliv nebyl prokázán.
\end{abstract}




\section{Introduction}

Foreign direct investment (FDI) is often viewed as a crucial part of economic development and job creation. Policymakers, therefore, often employ various FDI promotion measures such as direct FDI subsidies or tax reliefs. On the other hand, a sceptical stance towards FDI promotion finds the costs of such a policy too high and argues that investment inflow would have occurred even in the absence of the investment. Thus, the economic merit of FDI subsidies is not straightforward and should be subjected to careful analysis. An evaluation of the impact of FDI subsidies on the economy can be split into two parts: first, estimating the effect of subsidies on FDI inflow and its distribution, and, second, identifying the effect of FDI on productivity.

This paper concentrates on the former link between FDI subsidies and FDI attraction: it studies the impact of introducing a formal investment incentive scheme in the Czech Republic on regional distribution of FDI and assesses whether it is possible to alter location decisions of foreign investors. Specifically, using district-level data, the magnitude and the significance of changes in regional FDI per capita resulting from the adoption of the investment incentive program is quantified. ${ }^{1}$ In addition, the importance of conventional FDI determinants such as educational structure, industry structure and geographic factors is inspected.

Concerning the impact of FDI on economic growth and productivity, there exist a fair amount of studies identifying FDI as an engine of economic growth, employment generation and poverty alleviation (Campos and Kinoshita, 2002; Tondl and Vuksic, 2003). Apart from strengthening the competitive environment in a host country, FDI promotes international trade and enhances host country productivity through

\footnotetext{
${ }^{1}$ It should be noted that the focus of this analysis is not across-country FDI attraction, but rather within-country FDI allocation. In other words, assuming that FDI comes to the country, we study whether it is possible to direct FDI flows to distressed regions with the aid of government policy tools. Across-country comparison would require analysis of investment schemes of neighboring countries and is beyond the scope of this paper. For an across-country analysis of FDI determinants in transition countries, see, e.g., Bevan and Estrin (2000).
} 
multiple channels: capital formation, greenfields and takeovers, technology transfers, skill enhancements and knowledge spillovers. ${ }^{2}$ These spillovers occur when domestic firms improve their know-how by technology imitation or knowledge diffusion, or domestic workers increase their skills through training programs in foreign companies (Crozet et al., 2004) and can be realized through horizontal (competition within the sector) or vertical (supply) channels. Javorcik (2004) studies horizontal and vertical spillover effects in Lithuania between 1996-2000, finding no significant horizontal spillover effects. However, she finds a positive and significant vertical spillover effect of FDI on domestic firms. Concerning the Czech Republic, Stancik (2007) offers a summary of recent FDI spillover literature and analyzes the effects of FDI on the sales growth rate of domestic companies. He addresses a potential endogeneity of FDI with respect to future industry growth and finds negative horizontal and vertical effects, particularly in upstream sectors. In a more specific study of Czech takeovers, Jurajda and Stančík (2009) find a varying impact of foreign takeovers on domestic acquisitions according to industry sectors and target markets: the effect of takeovers on firms' various performance indicators is significantly positive for nonexporting manufacturing industries; while it decreases in the case of export-oriented firms and vanishes entirely for service-sector firms.

The role of FDI in the world economy rose steadily during last two decades, in especially in post-communist countries (see Figures 1 and 2). ${ }^{3}$ In the Czech Republic, a systematic approach to FDI promotion was adopted in 2001, providing foreign investors with a possibility to receive a financial subsidy per created vacancy or a retraining subsidy. A fundamental feature of this incentive system is that the exact amount of the subsidy is different across districts, offering higher investment incentives in districts with higher unemployment rates, thereby motivating investors to locate in more distressed regions. The identification strategy is based on a discontinuity represented by an unemployment level threshold which divides districts into

\footnotetext{
${ }^{2}$ See De Mello (1997) or Ozturk (2007) for a survey of literature on FDI growth effects.

${ }^{3}$ There was a modest decline in FDI flows in 2008 due to the global economic slowdown.
} 
several eligibility groups. Districts with the unemployment rate sufficiently close to a cutoff point are considered as randomly assigned into treatment and control groups, and a regression-discontinuity (RD) estimation is employed for identifying the causal impact of the program.

The motivation for this study is threefold. First, the topic is highly policyrelevant, and the evaluation of the investment incentives impact proposes practical implications: understanding the mechanisms behind foreign investors' decision process may improve policymakers' ability to direct FDI inflows into more distressed regions. Second, there is a lot of public money involved in investment policy funding, hence, from a social stance, it is necessary to assess the efficiency of the incentive system. On one hand, FDI inflow contributes to regional development and income growth (Wen, 2007), thereby decreasing public spending on unemployment benefits and social assistance. On the other hand, huge amounts of state subsidies require substantial budget spending. A proper evaluation of investment incentives requires a correct assessment of costs as well as benefits, the keystone being the identification of what would happen without the adoption of the scheme. Third, there is a lack of literature that rigorously evaluates investment incentives in the Central European region. This paper presents a contribution to the discussion on the role and appropriateness of public policies in FDI reallocation by combining a rigorous identification strategy and policy relevance.

\section{Literature survey}

Empirical studies on FDI determinants differ in the focus of their analysis - some concentrate on macroeconomic variables (gross domestic product, inflation, unemployment, price level) while others emphasize institutional (political climate, law enforcement) or location factors (quality of infrastructure, human capital endowment, proximity of target markets). Another segmentation of the research regards time 
horizon: studies adopt a cross-section of countries or panel data. An advantage of a panel dataset is that it allows the identification of important location determinants - such as a policy change - by exploiting the variation over time. Lastly, empirical literature concerning FDI determinants can be divided into between-country and within-country studies depending on whether it focuses on an international comparison or a regional analysis within a particular country. ${ }^{4}$

Considering within-country studies, seminal research on FDI inflow determinants is represented by Carlton (1983) and Coughlin et al. (1991), who analyze U.S. firms' location determinants on state and county levels. Analogical studies emerged in other countries such as Brazil (Hansen, 1987) or China (OECD, 2000). These studies focused on the relation between the characteristics of a region and FDI inflow. In the case of the U.S., states with a higher per capita income and higher manufacturing activity attracted FDI while higher wages and higher taxes deterred it (Coughlin et al., 1991). Specific to automotive-related industries, Smith and Florida (1994) find that agglomeration economies matter for Japanese manufacturing plants. New establishments preferred locations in close proximity to Japanese assemblers and with higher overall manufacturing density. Surprisingly, contrary to the prevailing literature, higher wages and higher concentration of minorities are recognized as positive and significant determinants of FDI inflow.

Country-specific studies suggest that significance of various FDI determinants differs across countries: in the case of Portugal, the strongest primary location factor is agglomeration of the service industry and the distance from principal cities, while regional labor costs do not matter in foreign firms' decision processes (Guimaraes et al., 2000). On the contrary, in an analysis of FDI location in Italy during 1986-1999, Basile (2004) finds local labor costs to be significant. Specifically, he claims that the main FDI determinants differ according to the type of foreign entry mode. Acquisitions are attracted by agglomeration economies, emulating the overall distribution

\footnotetext{
${ }^{4}$ See Bloningen (2005) for a comprehensive survey of literature on FDI determinants.
} 
of existing firms, and consider high-unemployment regions as less attractive for their location. On the contrary, greenfield investments are not affected by agglomeration economies and view high-unemployment regions as a signal of available labor force and thus attractive. Overall, the author assesses that FDI to the southern part of Italy is below its potential and calls for the implementation of regionally diversified fiscal policies in order to overcome large regional differences in economic growth.

Turning to the empirical evidence from the Czech Republic, Valachyová (2005) emphasizes that FDI inflow into the manufacturing sector follows the geographical distribution of the manufacturing industry at the beginning of transition. In addition, she observes a larger greenfield FDI influx for locations bordering with Germany and Austria and regions with better infrastructure and business services. Also, she finds a positive and statistically significant effect of industry-specific agglomeration.

International studies analyzing country-level FDI determinants find business environment, labor costs and the form of privatization process to be the most important factors influencing FDI inflow during transition (Lansbury et al. (1996) for Central European countries). Similarly, Bevan and Estrin (2000) find labor costs, the speed of reforms and political signals to significantly affect levels of FDI prior to the EU accession. In a more recent work, Jurajda and Terrell (2009) study regional disparities in post-communist economies and, among other issues, analyze regional patterns of FDI inflow. They find higher FDI flows into regions with a higher initial human capital endowment (measured as a share of college educated people at the end of communism).

Compared to papers studying fundamental FDI determinants, literature on investment incentives and FDI promotion policies is less numerous. There is an ongoing debate about the effectiveness of such policies. Some studies show that there exists a positive albeit small effect of using incentives to induce investment (Rainey and McNamara, 1999). Other papers, however, conclude that their role is insignif- 
icant and that investors' location is predominantly affected by primary location factors (Guimaraes et al., 1998; Mai, 2002). Examining agglomeration effects and regional policy impact on FDI in France, Crozet et al. (2004) find no evidence of a positive impact of regional policies on location choices, but they find a strong pattern of firm clustering. However, this effect fades out over time, suggesting a "learning process" of foreign investors as it becomes more important to be near target markets and less important to be a part of a cluster. On the same note, in their study of the Czech Republic, Hungary and Poland, Guagliano and Riela (2005) analyze the impact of industrial park designation on FDI attraction and their results show only a weak causal link between the presence of these special zone and FDI inflows.

As can be seen, the discussion about the purposefulness of investment incentives is far from being settled. This fact is emphasized by a stream of studies claiming the effect of incentives can not be generalized and depends on the form of incentives and its timing as well as the type and the size of the firm (Fox and Murray, 2004). Along this line, focusing on public incentives policy in Ireland, Barrios et al. (2006) find a positive effect of promotion policy only for low-tech firms and only during the period when a more "laissez-faire" approach to regional policy is introduced. Other studies document that the effect of public incentives on the economy is vanishing. Cannon (1980) analyzes the impact of incentives on employment and finds only transitory effect. Similarly, Schalk and Unitiedt (2000) claim that although the initial impact of incentive policy on attracting new investment is initially positive, it fails to permanently increase regional productivity and competitiveness in the long run.

In the case of the Czech Republic, there is a dearth of rigorous empirical literature evaluating the use of investment incentives, partly due to the initial absence of clear and stable rules for investment incentive schemes and a time delay needed for analyzing the impact of incentives. Valachyová (2005) marginally tackled this issue by analyzing separately FDI determinants for the set of all firms and the 
subset of firms receiving an investment incentive. The results for the infrastructure variable and foreign firms' agglomeration remained statistically the same, thereby implying a limited effect of an investment subsidy. Nevertheless, the evidence is not completely persuasive due to the lack of more comprehensive data capturing the incentive scheme framework and enabling identification of a causal relationship between FDI incentives and firm arrival. Therefore, the author admits, the results should be interpreted with caution.

\section{Institutional Background}

Foreign capital flows into the Czech Republic started in the early 1990s when the centrally-planned economy collapsed. Initially, the governmental stance towards FDI incentives was rather mixed. Soon, the need for foreign know-how and technology was recognized, and systematic state support of FDI began. ${ }^{5}$

Governmental support of FDI inflow started in 1998, providing foreign investors with an option to apply for a financial subsidy. However, the system lacked transparency and a clear set of predefined rules as decisions about FDI incentives, their magnitude, and regional allocation were fully at the discretion of the government. Therefore, the system was elaborated in 2000 , when a formalized scheme of investment incentives was established. ${ }^{6}$ Since then, three types of investment incentives have been implemented: the "investment incentives program for the manufacturing sector" (program "M") ${ }^{7}$, the "job creation support program for regions worst

\footnotetext{
${ }^{5}$ The government agency CzechInvest was established in 1992 for FDI promotion and administration.

${ }^{6}$ An investment incentive law (no. 72/2000) became effective on May 1, 2000, defining the rules and eligibility conditions for foreign as well as domestic investors. The Czech Republic became the first Central or Eastern European country with a clear investment incentive system defined by law.

${ }^{7}$ The program was the first and the largest investment incentive program and started on May 1s 2000, providing investors into the manufacturing sector with income-tax relief, job-creation subsidies and training and retraining subsidies after meeting certain criteria (these were notably the minimum invested amount and the number of created vacancies - see Table 1 for a detailed overview of these conditions and the changes in the program).
} 
affected by unemployment" (program "U") ${ }^{8}$ and the "framework program for the support of technology centres and the strategic services" (program "F"). ${ }^{9}$

A primary motivation for the adoption of the investment incentives scheme was to diminish regional disparities, compensate distressed peripheral districts in the Czech Republic and to increase their attractiveness to investors. This strategy was reflected by the setup of the incentive policy - with the exception of the program "F", it introduced different eligibility categories dependent on the district unemployment rate. Based on the local unemployment rate during the previous year, districts were split into four groups: "high-incentive", "medium-incentive", "low-incentive" and "no-incentive" group. The first group included districts with the local unemployment rate of at least 50 percent above the country average, districts with the local unemployment rate 25 percent (but less than 50 percent) above the country average were classified as medium-incentive and districts with above-average local unemployment rate (but smaller than 25 percent above the average) as low-incentive. Finally, no-incentive group consisted of districts with the local unemployment rate below the country average ${ }^{10}$ Eligibility of individual districts was reassessed every six months and, consequently, districts' eligibility could vary over time as districts could shift from one eligibility category to another (Table 3) or even become ineligible for incentives at all (Table 4). Unfortunately, it is difficult to identify the impact

\footnotetext{
${ }^{8}$ The program started on June 2, 2004, and ended on December 31, 2007. It was motivated by the intention to attract foreign firms to more distressed regions of the Czech Republic. Firms investing at least $10 \mathrm{mil}$. CZK and creating at least 10 vacancies were eligible for a financial support which took two forms - either a direct subsidy for each created vacancy or a subsidy for employee retraining (see Table 2 for more details about the program).

${ }^{9}$ Program "F", which was launched on June 2, 2002 and ended on December 31, 2007, was designed to attract R\&D activities and knowledge-based investors. Technology centers have been defined as establishments oriented towards innovation and strategic services have been specified as manufactures with a high added-value in knowledge-intensive sectors.

${ }^{10}$ The medium 25 percent threshold was replaced by 20 percent from 2006 (Table 1). Moving from a no-incentive group to a low-incentive group made a company eligible for 80,000 CZK (roughly 3,500 euros) subsidy per each created vacancy and a reimbursement of 25 percent of requalification expenses. Moving from a low-incentive to a medium-incentive group increased the direct subsidy by 50 percent to 4,750 euros and a requalification subsidy by additional 5 percentage points of expenses. A shift from a medium-incentive to a high-incentive group increased the direct subsidy by a 67 percent margin (to 7,000 euros) and the refund for requalification expenses increased by another 5 percentage points (to 35 percent of total expenses overall).
} 
of investment incentives on FDI in the case of districts with changing eligibility. Therefore, in order to remove noise from the data, we limit the sample to districts that changed eligibility category at most once during a given period. ${ }^{11}$ It should be noted that changing categories, particularly moving to a lower subsidy category, is in a sense an outcome of the program. However, studying the ultimate impact of incentives on unemployment is beyond the scope of this paper as we are interested primarily on the impact of investment incentives on FDI inflow. ${ }^{12}$

Only the first two programs are considered when evaluating the effectiveness of incentive policies due to identification issues (eligibility criteria being based on unemployment thresholds; discussed in "identification strategy" section). Nevertheless, these two programs promoted a vast majority of supported FDI projects (more than 97 percent), thereby justifying this approach. Another important feature is an institutional change in the design of program "M", virtually removing incentive eligibility for the first eligibility group (districts with above-average unemployment rate but smaller than 20 percent above the average) starting from 2005. Therefore, in order to reflect this methodical change in the program, the eligibility thresholds separating no- from low-incentive districts and low- from medium-incentive districts are grouped together when estimating a simple regression model. In doing so, the coefficient for the grouped variable represents an estimate an effect of the lowest available threshold on FDI inflow. For a regression-discontinuity analysis, the institutional change in design of program " $\mathrm{M}$ " is reflected by splitting the sample into periods 2000-2005 and 2006-2007. During the first period the impact at all three thresholds is inspected, while only the medium- and high-unemployment thresholds are studied during the later period.

\footnotetext{
${ }^{11}$ The following districts were dropped due to several changes in eligibility categories: Chrudim, Opava, Břeclav, Vsetín, Kroměříž and Frýdek-Místek.

${ }^{12}$ For an analysis of the impact of FDI on labor market conditions, see, e.g., Dinga and Munich (2010).
} 


\section{Methodology}

Following the theoretical literature, we consider a set of traditional FDI determinants, namely, human capital endowment proxied by the share of tertiary-educated productive labor force, industrial structure of employment (the share of employment in the manufacturing sector) and local labor costs. Another set of explanatory variables includes the share of arable land out of the total area of a district, connections to main highways and proximity to target markets. Also, the local unemployment rate and vacancy rate are included in the model.

The impact of human capital endowment on FDI is, ceteris paribus, expected to be positive. Industrial structure is also expected to exhibit a positive influence on FDI inflow due to industry-specific FDI flows (e.g., Guimaraes et al., 2000) and the fact that the majority of inward FDI in the Czech Republic comes into the manufacturing sector (more than 30 percent in 2006). ${ }^{13}$ Local labor costs are represented by a logarithm of average local wages. Obviously, holding other independent variables constant, firms are expected to show a strong tendency to locate their labor-intensive production in districts with low labor costs (Basile, 2004). However, low wages might reflect unobserved low productivity of the local labor force, therefore, high wages are expected to decrease FDI flows only if differences in wages are not outweighed by differences in labor productivity. A variable describing the share of arable land on the total area of a district is introduced to capture investors' possible preference for agricultural land and is expected to be positive. ${ }^{14}$

In empirical literature, distance between markets implies trade costs. The proximity of target markets exerts a positive influence inward FDI, increasing with the size of these markets and the levels of exports to these markets. In the case of the Czech Republic, Germany and Austria are the main export markets among

\footnotetext{
${ }^{13}$ Unfortunately, it is not possible to analyze FDI flows separately for different industries due to the nature of the FDI data - only aggregate values are available at the district level.

${ }^{14}$ It is known from anecdotal evidence that building up a new plant on agricultural land (greenfield investment) is usually cheaper than revitalizing an industrial site (brown-field investment).
} 
neighboring countries, thereby justifying the use of a dummy indicating a common border with these countries as an explanatory variable. This dummy is expected to take a positive sign. On the same note, a good connection to target markets diminishes transportation costs and, thus, a dummy indicating a connection of a particular district to the highway network is expected to have a positive sign. The unemployment and vacancy rates describe the tightness of the local labor market. A high unemployment rate increases the pool of available workforce and is expected to attract FDI inflow. On the contrary, a high vacancy rate indicates the lack of suitable workers and deters new FDI. ${ }^{15}$ The inclusion of the time trend captures an intertemporal variation in aggregate FDI due to macroeconomic and external factors.

The principal model is augmented by an investment incentive dummy, which indicates the eligibility of a particular district for some form of investment incentives. The purpose of FDI incentives is to increase the propensity of investors to locate in areas preferred by the government and, therefore, the sign of incentive dummy is expected to be positive.

Formally, foreign direct investment is assumed to be a function of following variables:

$$
F D I=f\left(E D U C, U N I, M A N U F, A G R I, H I G H W A Y, E U 15, w, u, v, t, t^{2}, I N C\right),
$$

where $E D U C$ is a share of productive labor force with completed secondary education, ${ }^{16} U N I$ is the share of tertiary educated productive labor force, $M A N U F$ is the share of employment in the manufacturing sector, $A G R I$ is the share of arable land, HIGHWAY indicates the presence of a highway, EU15 stands for the common

\footnotetext{
${ }^{15}$ High levels of both the unemployment and vacancy rates indicate a skill mismatch when there is a disporportion between skills supplied by labor force and skills demanded by firms.

${ }^{16}$ By completed secondary education we mean having passed school-leaving examinations (roughly corresponding to German "Abitur" exam or the U.K. General Certificate of Education) which are held at the end of all academic secondary schools and some vocational and specialized schools.
} 
border with the EU-15 (Austria and Germany), w stands for the local wage level, $u$ is the local unemployment rate, $v$ is the local vacancy rate, $t$ is the time trend and $I N C$ is the set of three incentive dummies (low-incentive, medium-incentive, high-incentive) indicating the eligibility category of a district for incentives.

In order to remove potential endogeneity of $E D U C, U N I, M A N U F, A G R I$ and $H I G H W A Y$, these variables are proxied by their "initial-period" values. Specifically, educational and industrial structure is taken for year 1997 and $A G R I$ and HIGHW AY for year 1996, i.e., years before massive FDI inflow occurred. Explanatory variables constructed in this way can be considered as exogenous with respect to future FDI inflow. Unemployment and vacancy rates can also be endogenous, leading to biased regression estimates. In order to overcome this endogeneity problem, the dependent variable $F D I$ is constructed as a forward-looking three-year average of yearly FDI inflow into a particular district. As a result, current FDI and vacancy rates can be considered as predetermined.

\section{Data}

We make use of various data sources. The information about FDI flows is obtained from the Czech National Bank and covers annual periods between 1998 and 2007 at the district level. ${ }^{17}$ Overall FDI consists of basic capital (deposit of non-resident in the form of fixed assets), reinvested earnings (profit not distributed as dividends) and other capital (loans from the parent company). Our goal is to identify the role of financial incentives on actual location decisions of new foreign firms. The best indicator of FDI incoming from new establishments is basic capital, therefore, only

\footnotetext{
${ }^{17} \mathrm{FDI}$ is defined according to OECD (1996): "Capital investment abroad is regarded as a foreign direct investment if the purpose is to establish permanent equity relation with a target company. The share of a foreign investment must be at least 10 per cent of the target firm's basic capital." The stock of FDI in a year $t$ is defined as a cumulative amount of FDI starting from 1989 to the end of the particular year. Annual FDI flows are calculated on a net basis as an outcome of credit and debit capital transactions between direct investors and their foreign affiliates. Hence, there exists a possibility of negative FDI flow in the case of reverse investment when some component of FDI (e.g., basic capital of the firm) decreases and this drop is not offset by the remaining FDI components.
} 
this part of FDI is considered for the purpose of our analysis. ${ }^{18}$ In addition, three main metropolitan districts - Prague, Brno and Ostrava - are excluded from the analysis as FDI for these cities is affected to a large extent by factors not related to existence of investment incentive schemes based on unemployment thresholds (programs "M" and "U"). These districts were the main recipients of FDI from program "F", the only program not imposing any criteria regarding the level of unemployment. This program was aimed at supporting FDI into technology centres and strategic services and attracted FDI almost exclusively to these metropolitan areas due to their specific position (university centers, qualified labor force, concentration of hi-tech industries). In addition, Prague, as a capital and the seat of head offices of large financial institutions, has been subject to substantial jumps in FDI flows due to privatization of banks and large one-off sales of state-owned enterprises. Moreover, there exists a discrepancy between actual and reported location of FDI: it is registered in a district where the head office is located, biasing the statistics for companies operating across districts. A typical example would be a large enterprise with its head office located in Prague that sets up a new branch in a particular district outside Prague. In such a case, even though the incentive is spent in this district, the new FDI is recorded in Prague. Fortunately, a list of FDI projects supported by programs "M" and "U" contains only a negligible amount of firms operating in more than one district, thus justifying the use of district-level FDI data for analyzing the incentive impact.

Other data sources are the Unemployment Registry (UR), the Labor Force Survey (LFS), Czech Statistical Office (CSO) and CzechInvest. The UR contains quarterly district-level data on unemployment and the CSO provides information on wages and geographic characteristics. The LFS includes individual data about labor market status, age, education, sector of employment and other characteristics

\footnotetext{
${ }^{18}$ The other two components of FDI - reinvested profit and remaining capital - are influenced by the internal decisions of existing firms and corresponding financial transactions, thereby not related to the existence of an incentive scheme.
} 
which serve as a basis for calculating the industry and education structure for each district on semi-annual basis. Investment incentives data are from the government agency CzechInvest ${ }^{19}$ and the Ministry of Labor and Social Affairs. It contains the list of subsidized investment projects as well as the list of districts eligible for state support during particular time periods.

Sample means for the analysis-ready data are showed in Table 5. There is a visible parabolic trend in FDI inflow per capita which justifies the use of a squared time trend in the regression.

\section{Descriptive Statistics}

Figure 3 shows the evolution of the total FDI stock in the Czech Republic between 1998 and 2006. Each box characterizes a regional distribution of overall FDI stock during a particular year on a logarithmic scale. An upward trend reveals a steady increase in the FDI stock, the persistence of regional variation and the dominance of Prague in FDI allocation. ${ }^{20}$ In absolute terms, while the overall stock of FDI in the Czech Republic was 429.2 billion CZK (roughly 17.5 billion euros) at the end of 1998 , by the end of 2006 it was 1,667 billion CZK ( 67 billion euros). Thereof, approximately one half of overall FDI stock in the Czech Republic is located in the capital city of Prague. This disproportion is even magnified if per capita levels are considered. Table 6 displays FDI inflows per capita for the three largest cities (Prague, Brno and Ostrava) as compared with the rest of the Czech Republic. The specific position of these metropolitan districts is documented by large regional disparities in FDI flows between them and the rest of the country, thereby justifying their exclusion from the analysis as described in the previous section.

In assessing the impact of the incentive scheme, it is important to realize differ-

\footnotetext{
${ }^{19}$ State agency promoting foreign direct investment.

${ }^{20}$ The box plot characterizes the distribution of the FDI stock - the median is represented by the white line inside the box, the quartiles by the edges of each box, the extreme values (thin lines extending from each box) and the outlier (Prague).
} 
ences in the unemployment rate both geographically and intertemporally. In Table 7 we see the evolution of the unemployment rate in the Czech Republic over time. It can be observed that the unemployment rate increased substantially in Ústecký and Moravskoslezský regions after the recession in the 1990s and has remained at high levels ever since. Hence, districts in those two regions were favored by the design of the incentive scheme as foreign investors locating there had an opportunity to obtain the most generous subsidy from the state.

Looking at the regional dimension of FDI, Table 8 displays an FDI inflow across regions during 2000-2007 and compares overall realized FDI inflow with the supported FDI inflow and direct investment subsidy. Two main characteristics can be observed from the table: first, except for Středočeský and Moravskoslezský region, a vast majority of investment inflow during 1999-2006 was supported by the state; second, for some regions the size of supported projects exceeds the realized FDI inflow. This observation can be attributed to the delay in the realization of the project awarded with a financial subsidy (towards the end of the time span 20002007, "supported FDI" may include also some projects which are yet to be realized and, thus, not included in the "realized FDI" data). Another explanation may be the discrepancy between the planned and realized investment as the amount of supported FDI is based on the data reported by the firm upon filing an application for investment incentive (i.e., prior to the realization of the investment) and may overstate the actual amount of realized FDI. ${ }^{21}$

FDI inflow per capita by the districts' eligibility for the financial subsidy after the implementation of the incentive scheme is shown in Table 9. One can observe that the basic capital part of FDI inflow is decreasing over time among eligible districts (with the exception of the "high-incentives" group where there is no visible trend). However, such a simple comparison is not enough for evaluating the causal impact

\footnotetext{
${ }^{21}$ The law n. 72/2000 about investment incentives specifies that the investor must maintain created jobs for at least 5 years and the investment must also contain non-public resources (at least 25 percent).
} 
of the incentive scheme. In the following section we present a rigorous identification strategy utilizing the regression-discontinuity setup and the role of unobservables in such a design.

\section{$7 \quad$ Identification Strategy}

The identification strategy is based on a strict unemployment threshold set by the Czech government which splits districts into several eligibility groups. Being set exogenously, this threshold provides an opportunity to employ the regressiondiscontinuity method (Imbens and Lemieux, 2007; Lee and Lemieux, 2009) which is designed to estimate the policy impact in the absence of a randomized controlled experiment. We assess the effectiveness of the incentive programs based on unemployment thresholds by analyzing the impact of the discontinuity in an assignment variable (the unemployment rate) on the outcome variable (the average FDI per capita in a district during three years following the year essential for eligibility criterion).

The main assumption justifying the use of RD design is that the assignment variable is observed and the assignment rule is ex-ante known (sharp RD design). By the setup of the investment incentive scheme, this assumption is satisfied. A key assumption, which we test statistically, is that there should be no discontinuities for control variables. Another assumption is that the outcome variable is a continuous and smooth function of the assignment variable in the absence of the treatment. While there exists no statistical way to test this assumption, the inspection of the outcome variable and the assignment variable prior to implementing the incentive scheme suggests that the RD approach is justified.

In the first step, we estimate a regression model characterized by equation (1), 
explaining the variation in FDI caused by observables:

$$
\begin{aligned}
F D I_{i t}= & \alpha+\beta_{1} E D U C_{i t}+\beta_{2} U N I_{i t}+\beta_{3} M A N U F_{i t}+\beta_{4} A G R I_{i t}+\beta_{5} H I G H W A Y_{i t}+ \\
& +\beta_{6} E U 15_{i t}+\beta_{7} \ln (w)_{i t}+\beta_{8} u_{i t}+\beta_{9} v_{i t}+\gamma_{1}\left(L O W I N C_{i t}+M E D I N C_{i t}\right)+ \\
& +\gamma_{2}\left(\text { HIGHINC }_{i t}\right)+\phi t+\eta t^{2}+\epsilon_{i t},
\end{aligned}
$$

where $F D I_{i t}$ is a three-year average basic capital inflow per capita in district $i$ starting in period $t$; explanatory variables are as described in the model and $\epsilon_{i t}$ is a noise term. Dummies $L O W I N C$ and $M E D I N C$ are grouped in order to reflect the institutional change which occurred in 2005, allowing us to identify the impact of receiving "at-least some subsidy" during the whole analyzed period.

Unfortunately, while shedding some light on the importance of time-invariant explanatory variables such as the initial level of the share of tertiary-educated people or manufacturing employment, a regression estimation (2) can potentially lead to biased estimates of the incentive dummies as it explains only the part of the variation in FDI caused by observables. However, the error term encompassing the variation caused by unobservables is not generally uncorrelated with the incentive dummy (that would be the case if the program eligibility was given randomly):

$$
E\left(I N V^{\prime} \epsilon\right) \neq 0
$$

In the second step, therefore, we augment equation (2) by district-level fixed effects. In this way, we remove the variation caused by unobserved heterogeneity (as well as time-invariant variables). The coefficients for incentive dummies from fixed-effects specification can serve as a benchmark for comparison with regressiondiscontinuity estimates which are obtained afterwards.

In the third step, we make use of the discontinuity design of the investment incentive scheme and employ a key regression-discontinuity assumption claiming that unobserved heterogeneity vanishes around the discontinuity points: 


$$
E\left(I N V^{\prime} \epsilon\right)=0, \quad \text { for subset of districts around cut-off point. }
$$

In other words, when considering only a subset of observations around the discontinuity points, the whole variation in $F D I$ can be attributed to observables. Filtering out the variation caused by observables minus incentive dummies, all remaining difference in the dependent variable $F D I$ can be attributed to changes in the investment dummies.

The regression-discontinuity estimation is performed by calculating two local linear regressions at both sides of the cutoff point. The difference in outcome predictions between these two regressions represents the impact of the program at the specified threshold. ${ }^{22}$ The size of the discontinuity jump is analyzed for all three thresholds and for two periods: 2000-2005 and 2006-2007 (due to an institutional change in the scheme design). Standard errors of the estimates are obtained by the bootstrapping technique. ${ }^{23}$

Two alternative estimates of the policy impact are presented. First, all districts are included in the RD estimation. As a robustness check, the analysis is performed on a subsample containing only districts which have experienced at most one switch between four eligibility categories. We report only estimates of the latter specification as using the subsample is more plausible for the purpose of our analysis. ${ }^{24}$ Another check of the robustness of the findings is done by using alternative bandwidths around discontinuity points.

\footnotetext{
${ }^{22}$ The estimation is performed in Stata, making use of the command $r d$ (Nichols, 2007). Various techniques are available for choosing the bandwidth and kernel. We adopt a triangle kernel and the default bandwidth so that it includes at least 30 observations on both sides of the boundary.

${ }^{23}$ Bootstrapping corrects underestimated standard errors. Conventional standard errors may be biased when the treatment variable rarely changes over time (Bertrand et al., 2004).

${ }^{24}$ As noted before, numerous shifts hinder a proper causal assessment of the scheme impact on FDI and may distort the estimates since the dependent variable is calculated as a forward-looking three-year average.
} 


\section{Results}

First we explore what was the influence of the initial labor market conditions across districts on FDI inflow. Table 10 reports pooled regression estimates of the impact of variables characterizing wages, educational and industry structure from the mid 1990s, as well as incentive dummies. The estimation is repeated for two periods: while the first part also includes years prior to the establishment of the formal FDI promotion scheme, the second one covers the years after the launch of all FDI incentive programs. It can be observed that during years without systematic state support, an increase in the tertiary-educated workforce by 1 percentage point increased the annual FDI inflow by almost 25 euros per capita. The magnitude and significance of this effect vanishes during years 2003-2007. Similarly, investors were initially inclined toward locations with higher wages (increasing annual FDI inflow by almost 12 euros per capita); this effect is suppressed during later years. Incentive dummies show no significance in this simple specification. However, after removing unobserved heterogeneity by including district-level fixed effects, there is a positive impact on FDI for the lowest threshold during both periods (Table 11). This results suggest there might exist a some positive effect of the incentive scheme.

Next, we exploit discontinuities around the cutoff points by performing RD estimation. Table 12 provides results of regression-discontinuity estimates based on three unemployment thresholds. The first three columns show the impact of the incentive scheme on FDI inflow for the period before 2004 and the next three columns report estimates of the impact of the scheme for the period 2005-2007. ${ }^{25}$ It can be observed that during the period 2000-2004, there is no significant impact of the incentive scheme at any threshold with the exception of the first threshold (the average unemployment), where using a short bandwidth indicates some positive effect of investment incentive on FDI inflow. This finding may be explained by the fact

\footnotetext{
${ }^{25}$ The break point reflects the launch of the second program ("F") and significant change of the parameters of the first program ("M").
} 
that while the incremental value of a subsidy at the first threshold is twice as much as at the second threshold $(80,000$ CZK vs. 40,000 CZK per created vacancy and 25 percent vs. 5 percent of retraining expenses).

In accordance with the institutional setup, as the first eligibility category was removed starting from 2005, there is no significant effect of the incentive scheme at this threshold during 2005-2007. However, contrary to period 2000-2004, the medium threshold displays a significant effect in the later period, increasing annual FDI inflow per capita by 328 euros. It corresponds to the mentioned change in the design: the medium threshold has become in fact the lowest threshold during the period 2005-2007 and may have "absorbed" the first-threshold effect on FDI inflow.

Estimates for the highest threshold exhibit a large variation depending on the bandwidth and, thus, no clear conclusion can be made about its impact on investors' choice of location. Moreover, in the case of this threshold, one of the labor market characteristics (vacancy rate) does not pass the test of being continuous around the threshold, which might affect the estimates for FDI inflow.

A visual presentation of the regression-discontinuity estimates helps to illustrate the findings: Figure 4 displays the impact of the incentive scheme on FDI per capita inflow for the lowest threshold. A significant effect is found only for years 2000-2004. After 2005, when the eligibility criteria tightened, the impact disappears. Accordingly, Figure 5 shows that although there is no significant effect for the medium-unemployment threshold before 2005, there is a substantial impact on FDI inflow starting from 2005, which is even more pronounced than in the case of the first threshold before 2005. Figure 6, illustrating the impact for the highest threshold, shows no prevailing trend in FDI inflow, as the estimation is affected by a smaller number of observations and the estimates of the discontinuity impact are insignificant for both periods.

Overall, the results suggest that investment incentives have some potential in relocating FDI. The findings document a positive impact of investment incentives 
particularly for the threshold splitting districts between ineligibility and "at-least some" eligibility categories. However, there is no evidence of any added value (in terms of increased FDI inflow) of the different scales of eligibilities - districts with more generous subsidies display no extra FDI inflow than districts with less generous investment subsidies. It seems that an option to obtain an investment subsidy played some role in foreign investors' allocation; however, they did not care that much about the amount of the subsidy. This interpretation suggests the extra money spent on increased subsidies for more generous categories were used inefficiently.

This notion leads us to important policy questions: is it worth spending public money on these policies? Or are there alternative tools of policymaking which could use public funding more efficiently? While a comprehensive answer to this question is beyond the scope of this paper, we partially answer the issue by roughly calculating the net employment effect of FDI subsidies. In a study of FDI employment effect by Dinga and Munich (2010), the net employment effect of a large and concentrated district-level FDI inflow in the Czech Republic is found to be 3.7 percent; however, their result regards the specific case of a 700 million euro project and a district of 68,000 residents. Combining this case with this paper's finding indicating that eligibility for the incentive program increases FDI per capita by 320 euros annually (1,000 euros during three years following the eligibility decision), we assume 68 million euros of FDI inflow into this benchmark district during three years. Further, assuming that the employment effect is proportional to the size of the investment gives use the employment impact of 240 jobs due to the investment scheme. ${ }^{26}$

Extending this back-of-the envelope analysis to some fiscal implications, we assume that all 240 jobs are filled with unemployed people. In other words, we do not take into account potential crowding-out across districts and across jobs and presume budget savings are as high as yearly state costs for 240 unemployed. According

\footnotetext{
${ }^{26} \mathrm{We}$ assume that a 700 million euro investment attracts 2,500 individuals (3.7 percent $\mathrm{x}$ productive labor force 68,000$)$ and 68 million euro investment attracts roughly 240 individuals (68 mil. / (700 mil. / 2,500)).
} 
to Elbona (2005), annual expense on 240 unemployed including direct unemployment benefits, taxes and social insurance contributions equals 42 million CZK. In comparison, for an investor with 240 job openings, the incentive scheme granted a subsidy of 19 million CZK (first eligibility group) to 48 million CZK (third eligibility group), suggesting that the use of investment incentives is a reasonable option from a policymaker's perspective (at least for the first threshold).

This is only a rough approximation illustrating the magnitude of the employment effect of FDI promotion incentives. The return and the pay-off time of investment incentives depends on the proportion of the crowding-out effect - assuming that all regionally reallocated FDI was attracted to the country just by the incentive scheme itself, the pay-off time would be 6 months and 14 months for the third eligibility group. If one half of the FDI would have come to the country in the absence of the investment incentive scheme anyway (i.e., there has been crowding-out across districts), the pay-off time would be twice as much. According to investment incentive law $72 / 2000$, the investor is required to maintain the created job for at least five years after the investment occurs. If this condition is satisfied, the net return on the investment incentives would be positive as long as at least 20 percent of reallocated FDI was not crowded out from other regions. However, this interpretation should be taken with caution as there were cases of supported companies which were not able to maintain the initial workforce due to the economic crisis. ${ }^{27}$ Moreover, government-driven policies did not work for the most distressed regions as there was no significant effect of the investment incentive for the third unemployment threshold.

\footnotetext{
${ }^{27}$ An infamous example of such a problematic investment project is represented by LG.Phillips in district Přerov. The company was not able to maintain the number of job openings as specified in the investment subsidy contract and eventually stopped production due to insolvency four years after the start of the production.
} 


\section{Conclusion}

This research has the ambition to unveil a source of regional disparities in FDI distribution in the Czech Republic and to identify main location determinants of foreign investors during 2001-2007. The emphasis is put on the role of investment incentives on regional allocation of FDI, as softening regional disparities and fostering new job creation in areas with above-average unemployment can bring substantial relief for public spending in terms of unemployment benefits and social assistance. Quantifying the impact of financial incentives on foreign investors' location decisions can uncover the true effect of these policies and shed more light on the justification of investment incentives.

The design of the investment incentive scheme in the Czech Republic allows the identification strategy to be based on differences around the cutoff discontinuity points. The identification is based on a regression-discontinuity estimation around three thresholds, classifying districts into three eligibility and one ineligibility categories. We estimate the impact of each threshold in FDI district-level reallocation across the Czech Republic. In other words, we only measure the policy impact on redistribution of FDI already attracted to the country (at the international level, FDI may be attracted by country-level variables; Bevan and Estrin, 2000).

During the period before 2004, regression-discontinuity estimates are positive and both economically and statistically significant only for the first threshold (the average unemployment rate) and smaller bandwidth, and the positive effect vanishes at the second threshold (1.25 x the average unemployment rate) and the third threshold (1.5 x the average unemployment rate). After the change in the institutional setup in 2004, implementing stricter unemployment conditions and removing the first eligibility category, there is a positive impact of the second threshold on FDI inflow, increasing annual FDI inflow per capita by 320 euros. Since this threshold became virtually the lowest unemployment threshold after 2004, it can be concluded that there is a positive impact of investment subsidies only for the lowest available 
unemployment threshold during the whole period. This findings is supported by the lack of the discontinuity impact for the medium threshold during 2001-2004 and for the lowest threshold during 2005-2007, respectively. The results provide no evidence of the significance of the incentive effect for the third threshold.

Overall, investors were initially inclined towards locations with educated workforce and relatively higher wages as rise in the share of tertiary-educated labor force by a percentage point increases the annual FDI inflow per capita significantly by 25 euros per capita during 2001-2004. Afterwards, the composition and determinants of FDI were altered and incentive variables became crucial factors in FDI attraction.

Performing a back-of-the-envelope calculation and comparing the costs of investment incentives with the benefits from saved costs on unemployment benefits, we argue that the adoption of the investment incentive scheme in the Czech Republic exhibits a positive net effect for the lowest unemployment threshold. While such approximations should be taken with caution, it gives the idea of the efficiency of investment subsidies. Summarizing, attraction of FDI can be efficiently supported from the state budget, with the exception of districts with the highest unemployment rate. Attracting FDI into the most distressed regions, thus, remains one of the important challenges for policymakers. 


\section{References}

[1] Barrios, S., Gorg, H., Strobl, E., 2006. Multinationals' Location Choice, Agglomeration Economies and Public Incentives. International Regional Science Review, 29 (1), 81-107.

[2] Basile, R., 2004. Acquisitions Versus Greenfield Investment: The Location of Foreign Manufacturers in Italy. Regional Science and Urban Economics, 34, $3-25$.

[3] Bertrand, M., Duflo, E., Mullainathan, S., 2004. How Much Should We Trust Difference-in-differences Estimates? The Quarterly Journal of Economics, 119 (1), 249-275.

[4] Bevan, A., Estrin, S., 2000. The Determinants of Foreign Direct Investment in Transition Economics. Working paper 342, William Davidson Institute.

[5] Bloningen, B. A., 2005. A Review of the Empirical Literature on FDI Determinants, Working Paper 11299, NBER, 1-37.

[6] Campos, N. F., Kinoshita, Y., 2002. Foreign Direct Investment as Technology Transferred: Some Panel Evidence from the Transition Economies. Working Paper 438, William Davidson Institute.

[7] Cannon, J., 1980. The Impact of Investment Incentives on Manufacturing Change: The Georgian Bay Region of Ontario. Canadian Geographer, 24, 131148.

[8] Carlton, D. W., 1983. The Location and Employment Choices of New Firms: An Econometric Model with Discrete and Continuous Endogenous Variables. The Review of Economics and Statistics, 65 (3), 440-449. 
[9] Coughlin, C. C., Terza, J. V., Arromdee, V. , 1991. State Characteristics and the Location of Foreign Direct Investment Within the United States. The Review of Economics and Statistics, 73 (4), 675-683.

[10] Crozet, M., T., Mucchielli, J.-L., 2004. How Do Firms Agglomerate? A study of FDI in France. Regional Science and Urban Economics, 34 (1), 27-54.

[11] De Mello, L. R., 1997. Foreign Direct Investment in Developing Countries and Growth: A Selective Survey. Journal of Development Studies, 34(1), 1-34.

[12] Dinga, M., Munich, D., 2010. The Impact of Territorially Concentrated FDI on Local Labor Markets: Evidence from the Czech Republic. Labour Economics $17,354-367$.

[13] Elbona, a.s., 2005. State Expenses Per One Unemployed. http://portal.mpsv.cz/sz/politikazamest/vyzkumnestudie/naklady1.zip.

[14] Fox, W. F., Murray, N. M., 2004. Do Economic Effects Justify the Use of Fiscal Incentives? Southern Economic Journal, 71, 78-92.

[15] Guagliano, C., Riela, S., 2005. Do Special Economic Areas Matter in Attracting FDI? Evidence from Poland, Hungary and Czech Republic. Working Paper 21, ISLA.

[16] Guimaraes, P., Figueirendo, O., Woodward, D., 2000. Agglomeration and the Location of Foreign Direct Investment in Portugal. Journal of Urban Economics, 47 (1), 115-135.

[17] Guimaraes, P., Rolfe, R. J., Woodward, D. P., 1998. Regional Incentives and Industrial Location in Puerto Rico. International Regional Science Review, 21, 119-138.

[18] Hansen, E. R., 1987, Industrial Location Choice in Sao Paolo, Brazil. A Nested Logit Model. Regional Science and Urban Economics, 17 (1), 89-108. 
[19] Imbens, G., Lemieux, T., 2007. Regression Discontinuity Designs: A Guide to Practice. Working Paper 13039, NBER.

[20] Javorcik, B.S., 2004. Does Foreign Direct Investment Increase the Productivity of Domestic Firms? In Search of Spillovers through Backward Linkages. American Economic Review, 94 (3), 605-627.

[21] Jurajda, Š., Stančík, J., 2009. Foreign Ownership and Corporate Performance: The Czech Republic at EU Entry. Working Paper 389, CERGE-EI.

[22] Jurajda, Š., Terrell, C., 2009. Regional Unemployment and Human Capital in Transition Economies. The Economics of Transition, 17 (2), 241-274.

[23] Lansbury, M., Pain, N., Smidkova, K., 1996. Foreign Direct Investment in Central Europe since 1990: An Econometric Study. National Institute Economic Review, 156, 104-113.

[24] Lee, D. S., Lemieux, T., 2009. Regression Discontinuity Designs in Economics, Working Paper 14723, NBER, 1-103.

[25] Mai, P. H., 2002. Regional Economic Development and the Foreign Direct Investment Flows in Vietnam 1998-98. Journal of the Asia Pacific Economy, 7, $182-202$.

[26] Nichols, A., 2007. Causal Inference with Observational Data. Stata Journal 7 (4), 507-541.

[27] OECD, 1996. Benchmark Definition of Foreign Direct Investment. OECD, Paris.

[28] OECD, 2000. Main Determinants and Impacts of Foreign Direct Investment on China's Economy. Working Papers on International Investment (2000/4), OECD, Paris. 
[29] Rainey, D. V., McNamara, K. T., 1999. Taxes and the Location Decision of Manufacturing Establishments. Review of Agricultural Economics, 21(1), 8698.

[30] Schalk, H. H., Unitiedt, G., 2000. Regional Investment Incentives in Germany: Impacts on Factor Demand and Growth. Annals of Regional Science, 34, 173195.

[31] Smith, D. F., Florida, R., 1994. Agglomeration and Industrial Location: An Econometric Analysis of Japanese-Affiliated Manufacturing Establishments in Automotive-Related Industries. Journal of Urban Economics, 36, 23-41.

[32] Stančík, J., 2007. Horizontal and Vertical FDI Spillovers: Recent Evidence from the Czech Republic. Working Paper 340, CERGE-EI.

[33] Tondl, G., Vuksic, G., 2003. What Makes Regions in Eastern Europe Catching Up? The Role of Foreign Direct Investment. Human Resources and Geography, Working Paper 51, IEF, Vienna.

[34] Valachyová, J., 2005. The Essays on Foreign Investments and Economic Geography: Empirical Investigation of the Czech Manufacturing Sector. PhD thesis, CERGE-EI, 1-95.

[35] Wen, M., 2007. Foreign Direct Investment, Regional Market Conditions and Regional Development: A Panel Study on China. Economics of Transition, 15 (1), 125-151. 
Figure 1: Overall stock of FDI in transition countries and Germany

FDI stock as the share of GDP

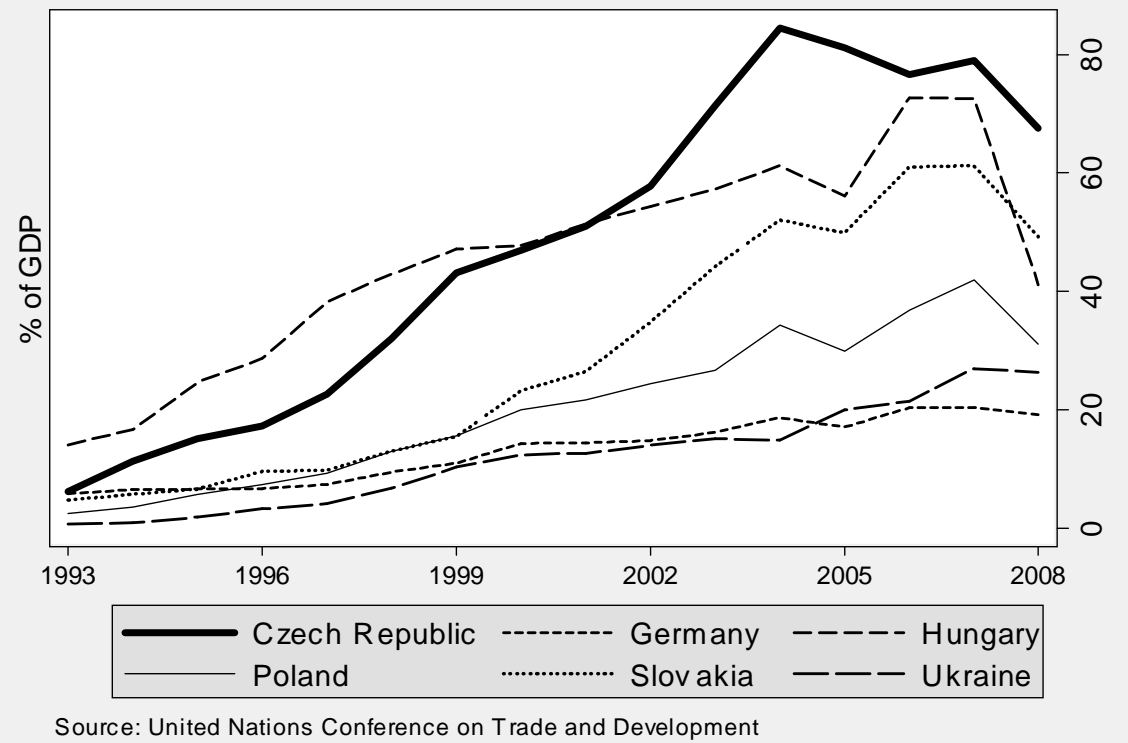

Figure 2: FDI inflow in transition countries and Germany

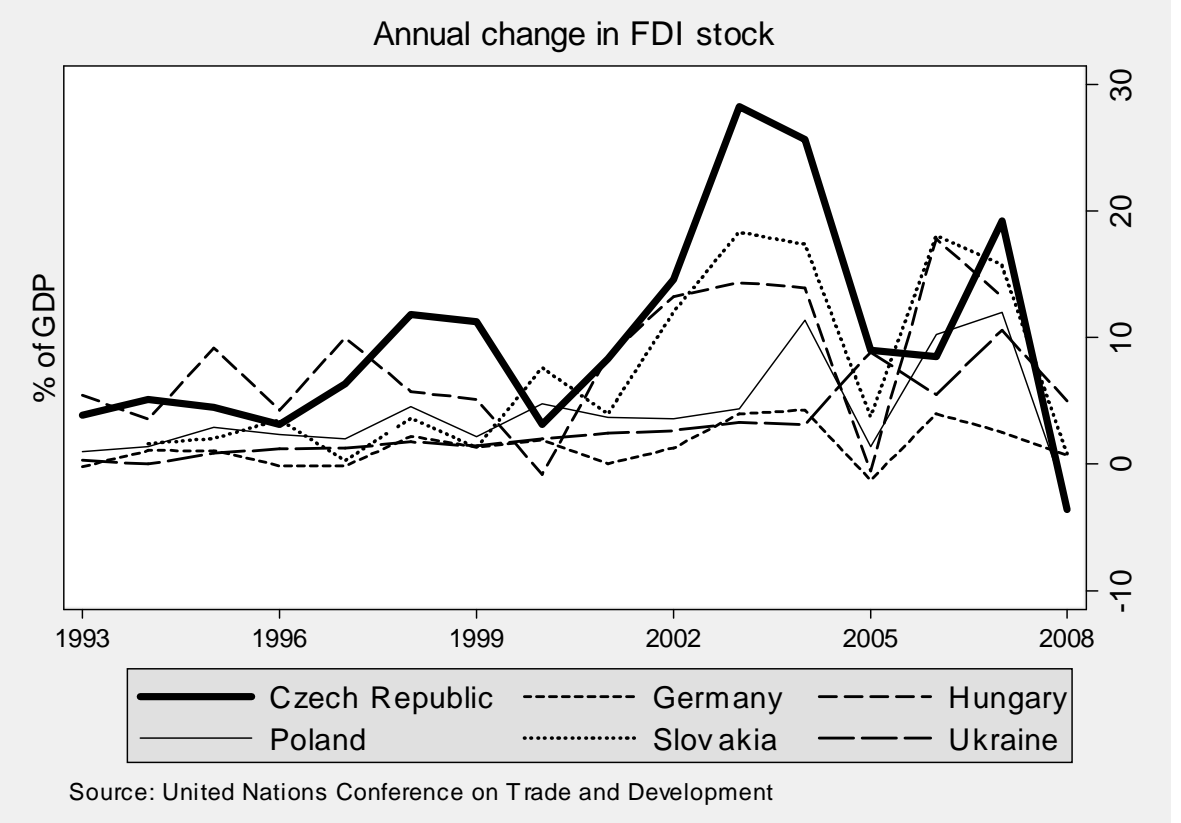


Figure 3: Realized stock of FDI across Czech regions (logarithms)

\section{Boxplot - stock of FDI}

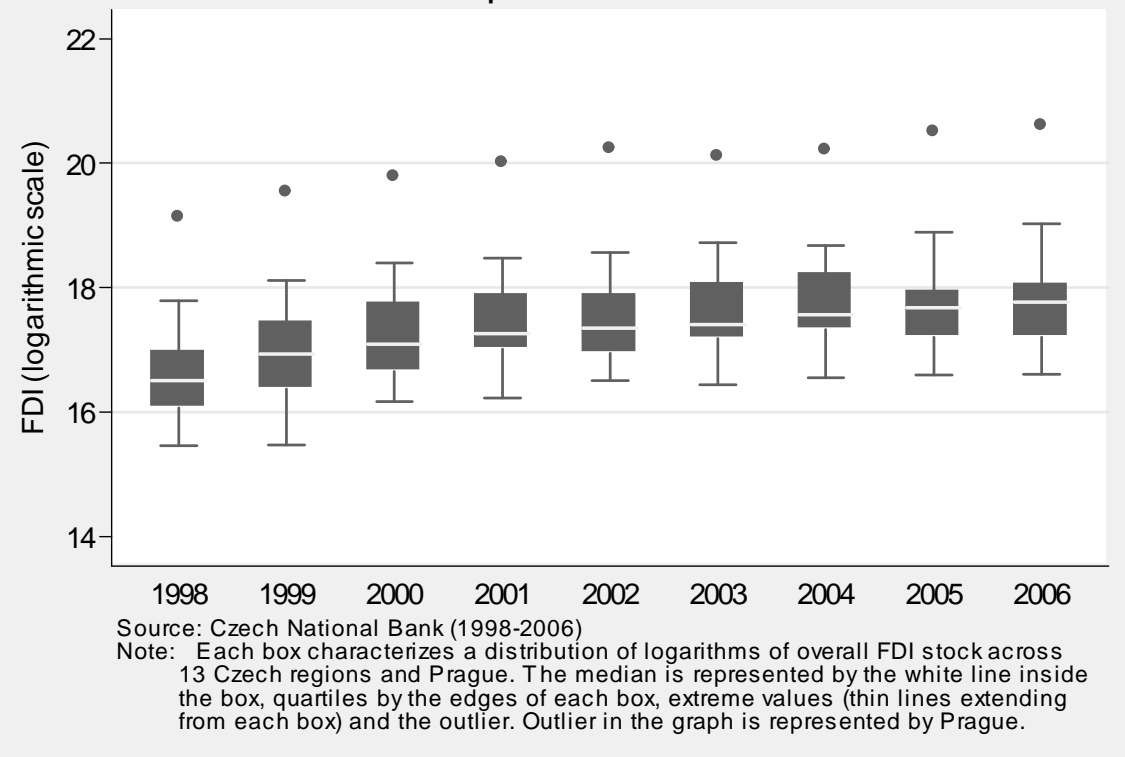

Figure 4: Regression discontinuity at the first threshold (low)

The discontinuity at the first threshold $(L)$
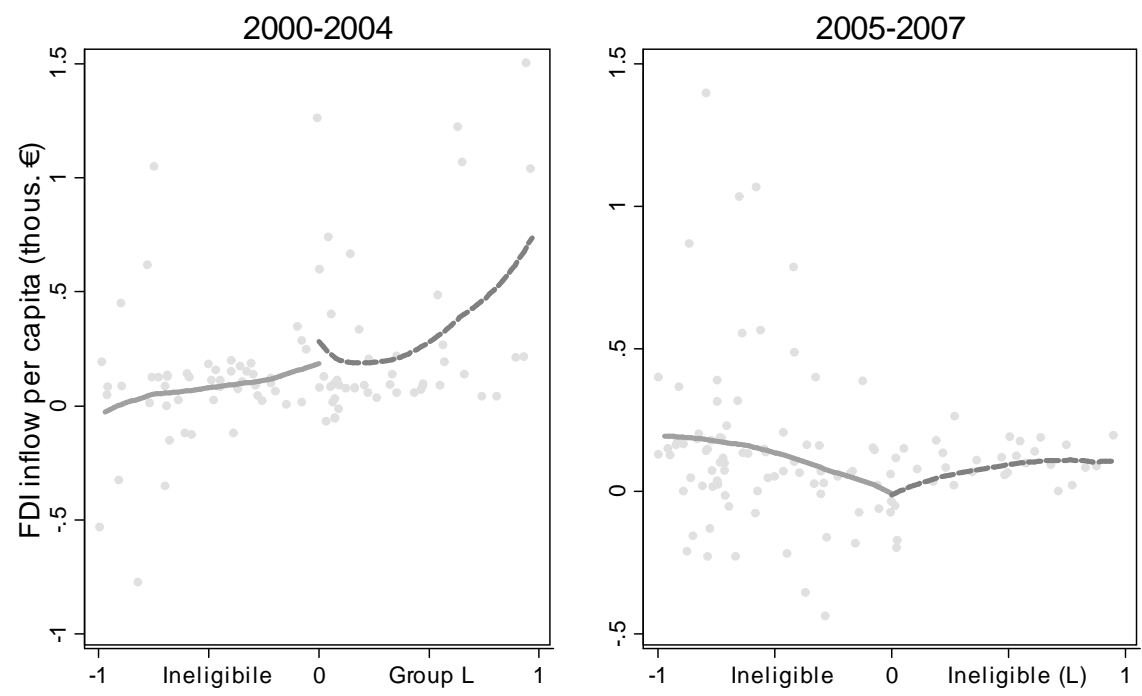

Note: Horizontal axis displays the difference between district-level and country-average Urate The cutoff point represents the country-average unemployment rate 
Figure 5: Regression discontinuity at the second threshold (medium)

The discontinuity at the second threshold $(\mathrm{M})$
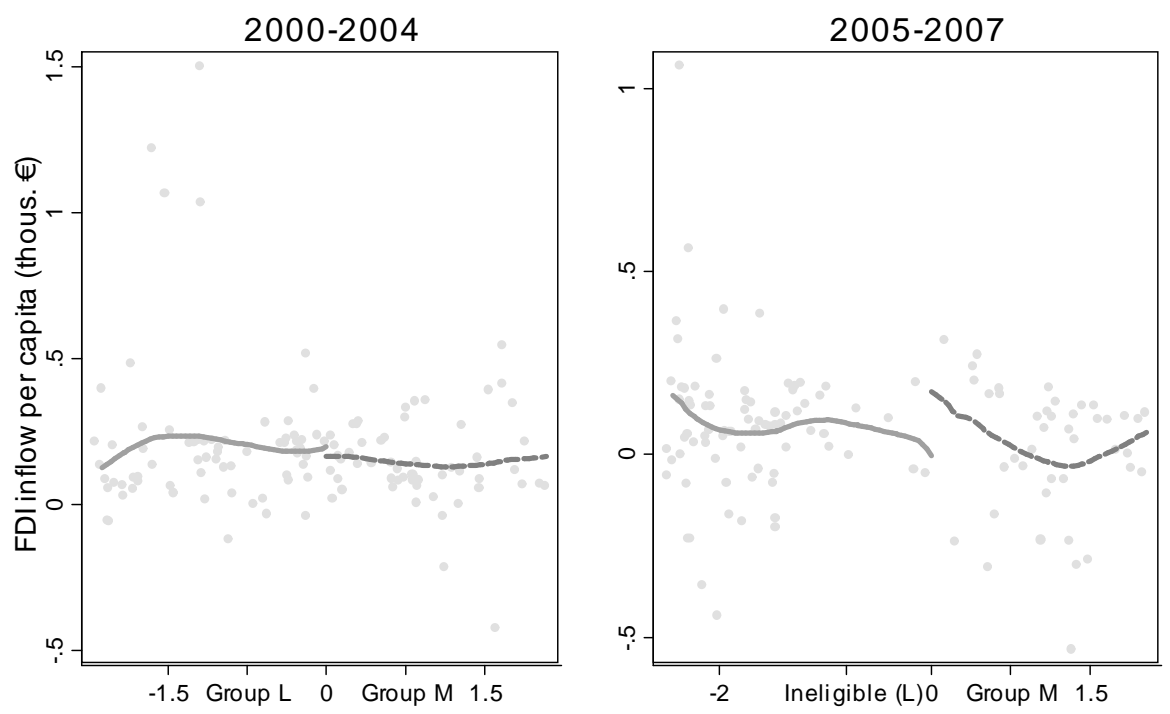

Note: Horizontal axis displays the difference between the district-level Urate and eligibility Urate (1.25xU_avg) The cutoff point represents $1.25 \mathrm{x}$ the country-average unemployment rate

Figure 6: Regression discontinuity at the third threshold (high)

The discontinuity at the third threshold $(\mathrm{H})$
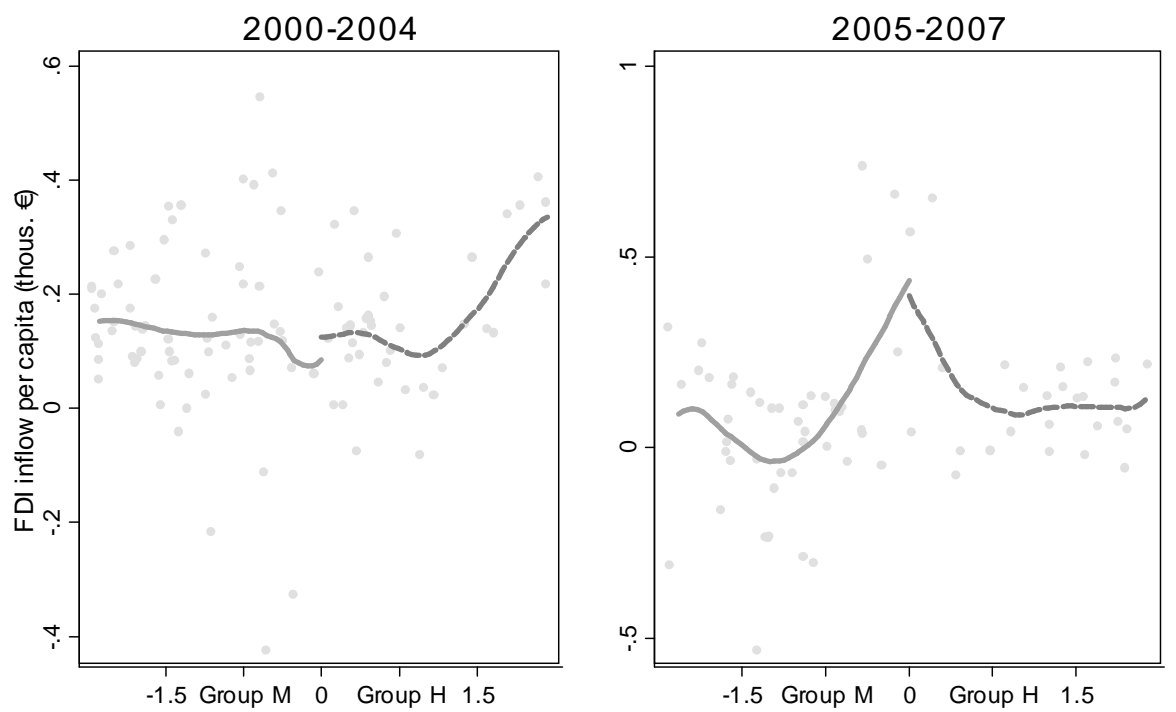

Note: Horizontal axis displays the difference between the district-level Urate and the eligibility rate (1.5xU_avg) The cutoff point represents $1.5 \mathrm{x}$ the country-average unemployment rate 


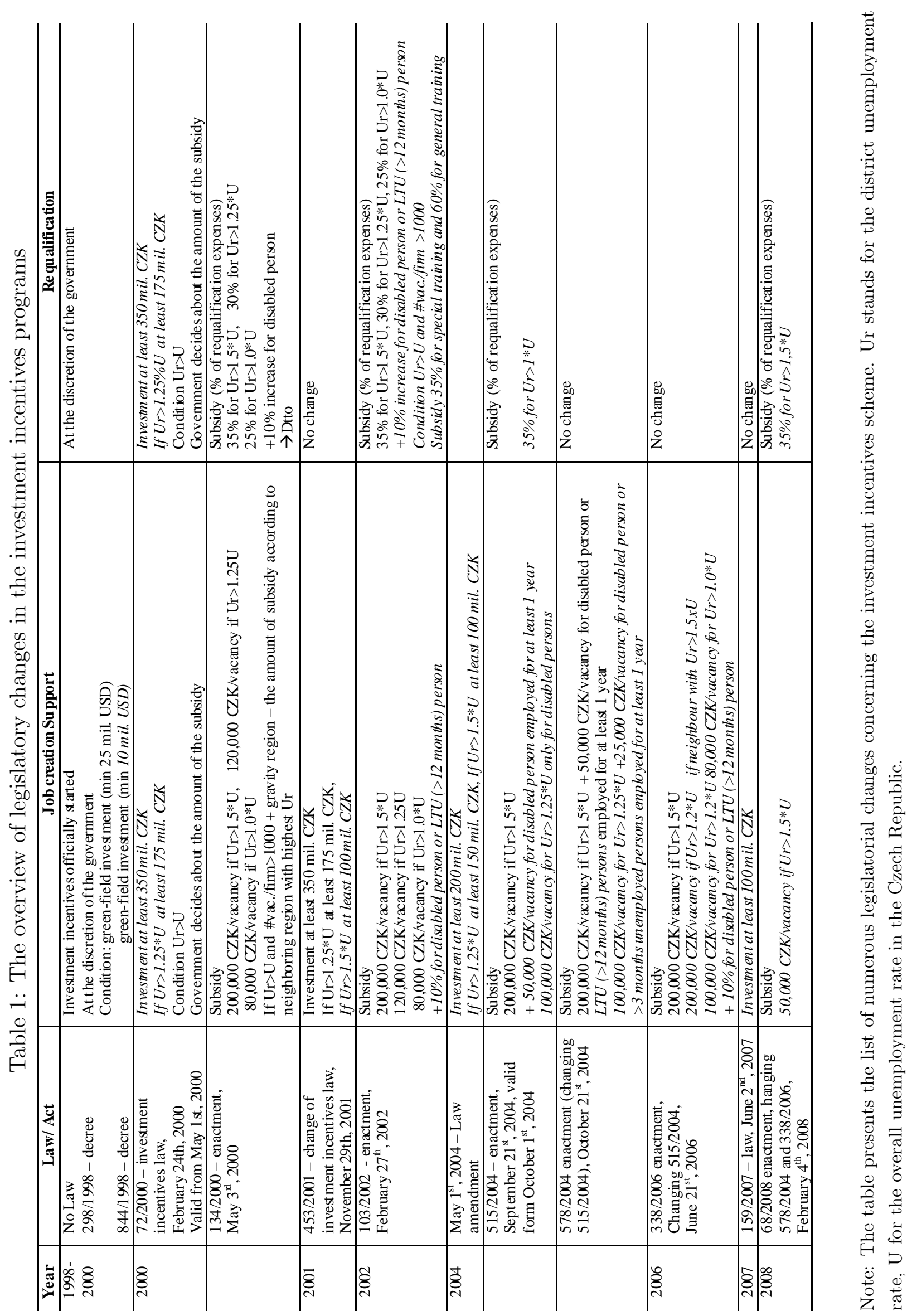




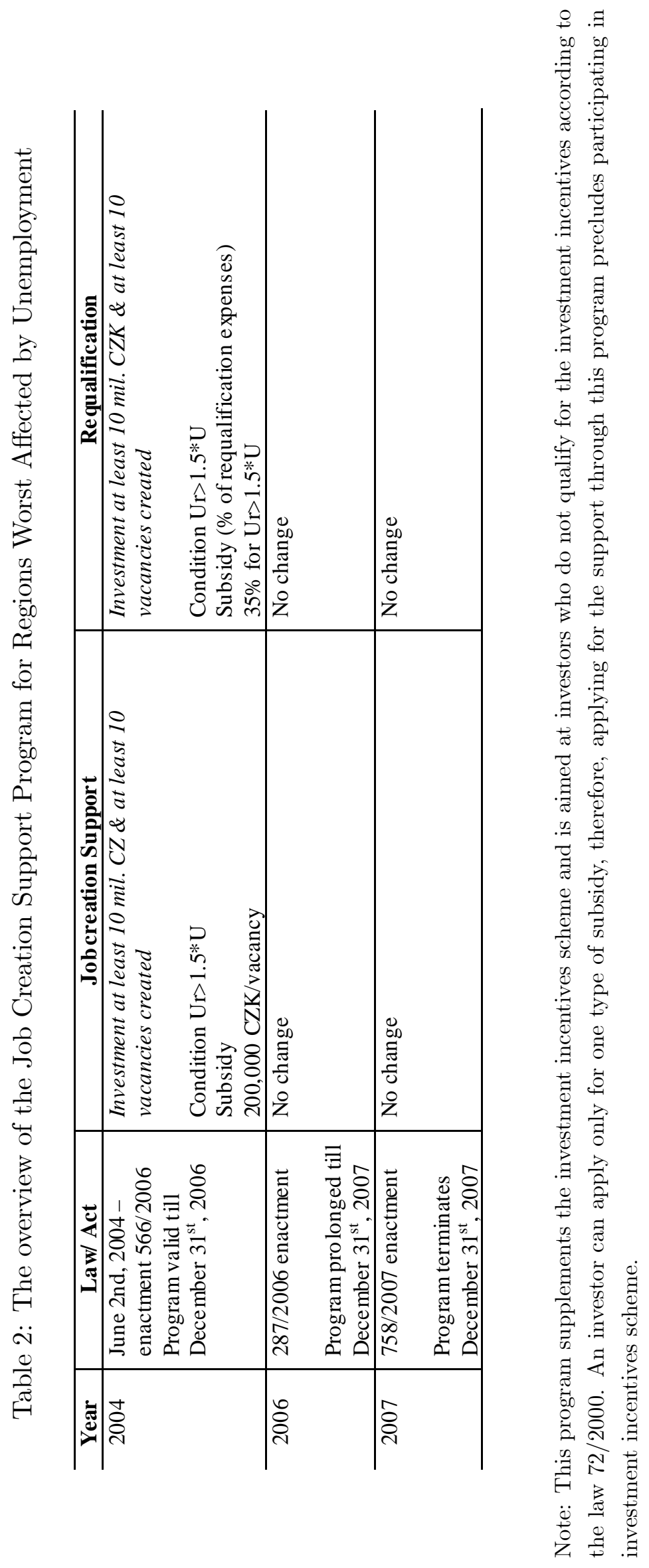


Table 3: The list of districts eligible for investment incentives for the whole period

\begin{tabular}{lccccc|ccc}
\hline \hline & 2000 & 2001 & 2002 & 2003 & 2004 & 2005 & 2006 & 2007 \\
\hline Sokolov & $\mathrm{L}$ & $\mathrm{M}$ & $\mathrm{M}$ & $\mathrm{M}$ & $\mathrm{M}$ & $\mathrm{M}$ & $\mathrm{M}$ & $\mathrm{M}$ \\
Děćín & $\mathrm{H}$ & $\mathrm{H}$ & $\mathrm{H}$ & $\mathrm{H}$ & $\mathrm{H}$ & $\mathrm{H}$ & $\mathrm{H}$ & $\mathrm{H}$ \\
Chomutov & $\mathrm{H}$ & $\mathrm{H}$ & $\mathrm{H}$ & $\mathrm{H}$ & $\mathrm{H}$ & $\mathrm{H}$ & $\mathrm{H}$ & $\mathrm{H}$ \\
Litoměřice & $\mathrm{M}$ & $\mathrm{M}$ & $\mathrm{M}$ & $\mathrm{M}$ & $\mathrm{M}$ & $\mathrm{M}$ & $\mathrm{M}$ & $\mathrm{M}$ \\
Louny & $\mathrm{H}$ & $\mathrm{H}$ & $\mathrm{H}$ & $\mathrm{H}$ & $\mathrm{H}$ & $\mathrm{H}$ & $\mathrm{M}$ & $\mathrm{H}$ \\
Most & $\mathrm{H}$ & $\mathrm{H}$ & $\mathrm{H}$ & $\mathrm{H}$ & $\mathrm{H}$ & $\mathrm{H}$ & $\mathrm{H}$ & $\mathrm{H}$ \\
Teplice & $\mathrm{H}$ & $\mathrm{H}$ & $\mathrm{H}$ & $\mathrm{H}$ & $\mathrm{H}$ & $\mathrm{H}$ & $\mathrm{H}$ & $\mathrm{H}$ \\
Ústí nad Labem & $\mathrm{H}$ & $\mathrm{H}$ & $\mathrm{H}$ & $\mathrm{H}$ & $\mathrm{H}$ & $\mathrm{M}$ & $\mathrm{H}$ & $\mathrm{H}$ \\
Svitavy & $\mathrm{M}$ & $\mathrm{M}$ & $\mathrm{M}$ & $\mathrm{M}$ & $\mathrm{M}$ & $\mathrm{M}$ & $\mathrm{M}$ & $\mathrm{M}$ \\
Hodonín & $\mathrm{H}$ & $\mathrm{H}$ & $\mathrm{H}$ & $\mathrm{H}$ & $\mathrm{H}$ & $\mathrm{H}$ & $\mathrm{H}$ & $\mathrm{H}$ \\
Třebíć & $\mathrm{M}$ & $\mathrm{M}$ & $\mathrm{M}$ & $\mathrm{M}$ & $\mathrm{M}$ & $\mathrm{M}$ & $\mathrm{M}$ & $\mathrm{M}$ \\
Znojmo & $\mathrm{M}$ & $\mathrm{M}$ & $\mathrm{M}$ & $\mathrm{M}$ & $\mathrm{M}$ & $\mathrm{M}$ & $\mathrm{H}$ & $\mathrm{H}$ \\
Bruntál & $\mathrm{H}$ & $\mathrm{H}$ & $\mathrm{H}$ & $\mathrm{H}$ & $\mathrm{H}$ & $\mathrm{H}$ & $\mathrm{H}$ & $\mathrm{H}$ \\
Frýdek-Místek & $\mathrm{H}$ & $\mathrm{H}$ & $\mathrm{H}$ & $\mathrm{H}$ & $\mathrm{M}$ & $\mathrm{H}$ & $\mathrm{M}$ & $\mathrm{M}$ \\
Karviná & $\mathrm{H}$ & $\mathrm{H}$ & $\mathrm{H}$ & $\mathrm{H}$ & $\mathrm{H}$ & $\mathrm{H}$ & $\mathrm{H}$ & $\mathrm{H}$ \\
Nový Jičín & $\mathrm{M}$ & $\mathrm{M}$ & $\mathrm{M}$ & $\mathrm{M}$ & $\mathrm{M}$ & $\mathrm{M}$ & $\mathrm{M}$ & $\mathrm{H}$ \\
Přerov & $\mathrm{H}$ & $\mathrm{H}$ & $\mathrm{H}$ & $\mathrm{H}$ & $\mathrm{M}$ & $\mathrm{M}$ & $\mathrm{M}$ & $\mathrm{M}$ \\
Šumperk & $\mathrm{M}$ & $\mathrm{M}$ & $\mathrm{M}$ & $\mathrm{M}$ & $\mathrm{M}$ & $\mathrm{M}$ & $\mathrm{M}$ & $\mathrm{M}$ \\
Jeseník & $\mathrm{H}$ & $\mathrm{H}$ & $\mathrm{H}$ & $\mathrm{H}$ & $\mathrm{H}$ & $\mathrm{H}$ & $\mathrm{H}$ & $\mathrm{H}$ \\
\hline \hline
\end{tabular}

Note: $\mathrm{H}$ stands for district with the unemployment rate above $1.5^{*} \mathrm{U}_{-}$avg, $\mathrm{M}$ for districts with the unemployment rate between $1.25 * \mathrm{U}_{-}$avg and $1.5 * \mathrm{U}_{-}$avg and $\mathrm{L}$ for districts with the unemployment rate between $\mathrm{U}$ and $1.25^{*} \mathrm{U}_{\text {_avg. }}$.

Table 4: The list of districts eligible for investment incentives only during some periods

\begin{tabular}{lccccc|ccc}
\hline \hline & 2000 & 2001 & 2002 & 2003 & 2004 & 2005 & 2006 & 2007 \\
\hline Kladno & $\mathrm{L}$ & $\mathrm{L}$ & $\mathrm{L}$ & $\mathrm{L}$ & $\mathrm{L}$ & & & \\
Kolín & $\mathrm{L}$ & $\mathrm{L}$ & $\mathrm{L}$ & $\mathrm{L}$ & $\mathrm{L}$ & & & \\
Břeclav & $\mathrm{L}$ & $\mathrm{L}$ & $\mathrm{L}$ & $\mathrm{L}$ & $\mathrm{L}$ & & $\mathrm{M}$ & $\mathrm{M}$ \\
Kroměříz & $\mathrm{L}$ & $\mathrm{L}$ & $\mathrm{L}$ & $\mathrm{L}$ & $\mathrm{L}$ & & $\mathrm{M}$ & $\mathrm{M}$ \\
Vsetín & $\mathrm{L}$ & $\mathrm{L}$ & $\mathrm{L}$ & $\mathrm{L}$ & $\mathrm{L}$ & & $\mathrm{M}$ & $\mathrm{M}$ \\
Kutná Hora & $\mathrm{M}$ & $\mathrm{M}$ & $\mathrm{M}$ & $\mathrm{M}$ & $\mathrm{M}$ & & & \\
Nymburk & $\mathrm{L}$ & $\mathrm{L}$ & $\mathrm{L}$ & & & & & \\
Opava & $\mathrm{M}$ & $\mathrm{M}$ & $\mathrm{M}$ & $\mathrm{M}$ & $\mathrm{L}$ & & $\mathrm{M}$ & $\mathrm{M}$ \\
Olomouc & $\mathrm{M}$ & $\mathrm{M}$ & $\mathrm{M}$ & $\mathrm{M}$ & $\mathrm{L}$ & & & \\
Karlovy Vary & & & $\mathrm{L}$ & $\mathrm{L}$ & $\mathrm{L}$ & & & \\
Čská Lípa & $\mathrm{L}$ & & & & & & & \\
Liberec & & & & & $\mathrm{L}$ & & & \\
Chrudim & $\mathrm{L}$ & $\mathrm{L}$ & & $\mathrm{L}$ & & & & \\
Prostějov & $\mathrm{L}$ & $\mathrm{L}$ & $\mathrm{L}$ & $\mathrm{L}$ & & & & \\
Vyškov & $\mathrm{L}$ & $\mathrm{L}$ & $\mathrm{L}$ & $\mathrm{L}$ & $\mathrm{L}$ & & & \\
\hline \hline
\end{tabular}

Note: $\mathrm{H}$ stands for district with the unemployment rate above $1.5^{*} \mathrm{U}_{-}$avg, $\mathrm{M}$ for districts with the unemployment rate between $1.25^{*} \mathrm{U}_{-}$avg and $1.5^{*} \mathrm{U}_{\text {_avg }}$ and $\mathrm{L}$ for districts with the unemployment rate between $\mathrm{U}$ and $1.25^{*} \mathrm{U}_{-}$avg. Staring from 2005, category L was abandoned as there remained only eligibility categories $\mathrm{M}$ and $\mathrm{H}$. 
Table 5: Descriptive statistics: the Czech Republic (means)

\begin{tabular}{c|c|c|c|c|c|c|c|c|c|c}
\hline \hline Year & \multicolumn{1}{|c|}{ FDI } & EDUC & UNI & MANUF & AGRI & $\ln (\mathrm{w})$ & HIGHWAY & EU15 & u_rate & v_rate \\
\hline 1998 & 306.4 & 78.9 & 6.26 & 30.7 & 39.5 & 9.27 & 0.24 & 0.26 & 6.87 & 1.11 \\
1999 & 320.0 & 79.5 & 6.34 & 31.0 & 39.4 & 9.35 & 0.24 & 0.26 & 9.09 & 0.84 \\
2000 & 269.6 & 78.5 & 6.57 & 30.9 & 39.3 & 9.41 & 0.24 & 0.26 & 8.75 & 1.18 \\
2001 & 127.3 & 78.5 & 6.82 & 31.4 & 39.2 & 9.47 & 0.26 & 0.26 & 8.48 & 1.28 \\
2002 & 97.6 & 80.0 & 7.29 & 31.2 & 39.1 & 9.53 & 0.26 & 0.26 & 9.28 & 0.95 \\
2003 & 111.3 & 80.1 & 7.43 & 30.6 & 39.0 & 9.60 & 0.26 & 0.26 & 9.96 & 0.85 \\
2004 & 219.9 & 81.1 & 7.72 & 30.6 & 38.9 & 9.66 & 0.30 & 0.26 & 10.08 & 0.89 \\
2005 & 330.6 & 82.1 & 8.28 & 31.7 & 38.8 & 9.71 & 0.31 & 0.26 & 9.49 & 0.98 \\
2006 & 329.2 & 82.4 & 8.71 & 32.3 & 38.7 & 9.75 & 0.34 & 0.26 & 8.46 & 1.65 \\
2007 & 362.4 & 82.0 & 8.90 & 32.9 & 38.6 & 9.79 & 0.35 & 0.26 & 6.82 & 2.37 \\
\hline \hline
\end{tabular}

Note: FDI is the forward-looking three-year average of basic capital inflow per capita in Euros, EDUC is the share of productive labor force with completed secondary education, UNI is the share of tertiary educated productive labor force, MANUF is the share of employment in manufacturing sector, AGRI is the share of arable land, HIGHWAY indicates the presence of a highway and EU15 stands for the common border with the EU-15 (Austria and Germany).

Table 6: Average FDI per capita inflow in the Czech Republic (euros)

\begin{tabular}{ccrr} 
Year & Czech Republic & 3 largest & Rest \\
\hline 1999 & 320.0 & $1,099.4$ & 144.2 \\
2000 & 269.6 & $1,016.2$ & 102.0 \\
2001 & 127.3 & 362.1 & 75.5 \\
2002 & 97.6 & 212.9 & 72.0 \\
2003 & 111.3 & 332.1 & 62.4 \\
2004 & 219.9 & $1,085.2$ & 28.9 \\
2005 & 330.6 & $1,419.8$ & 89.6 \\
2006 & 329.2 & $1,305.7$ & 113.1 \\
\hline \hline
\end{tabular}

Note: For the calculation of average FDI per capita inflow the three years following the year pivotal for eligibility decision were considered. The three largest cities are represented by the metropolitan areas of Prague, Brno and Ostrava. 
Table 7: Unemployment rate in Czech regions over time (\% of labor force)

\begin{tabular}{lrrrr}
\hline \hline & 1995 & 1999 & 2003 & 2007 \\
\hline Prague & 0.3 & 3.2 & 3.9 & 2.8 \\
Stredocesky & 2.7 & 6.9 & 7.2 & 5.4 \\
Pardubicky & 2.7 & 8.1 & 8.7 & 6.8 \\
Kralovehradecky & 2.1 & 6.9 & 10.2 & 5.6 \\
Liberecky & 2.3 & 7.7 & 9.2 & 7.4 \\
Ustecky & 5.8 & 14.7 & 17.4 & 14.0 \\
Karlovarsky & 1.8 & 8.1 & 10.2 & 9.3 \\
Plzensky & 2.3 & 6.9 & 7.3 & 5.6 \\
Jihocesky & 2.0 & 6.2 & 6.4 & 5.8 \\
Zlinsky & 2.7 & 8.1 & 10.3 & 8.0 \\
Vysocina & 3.6 & 8.4 & 8.6 & 7.1 \\
Jihomoravsky & 3.0 & 9.0 & 11.1 & 8.9 \\
Olomoucky & 4.6 & 11.4 & 12.0 & 9.0 \\
Moravskoslezsky & 5.7 & 13.5 & 16.4 & 12.9 \\
\hline Czech Republic & 3.1 & 8.6 & 10.0 & 7.8 \\
\hline \hline
\end{tabular}

Note: Regional unemployment rates for years 1995, 1999 and 2003 were calculated by merging together districts corresponding to a particular region according to the structural division as of 2007 (there was a change in regional structure starting June 2004).

Table 8: FDI inflow, supported FDI and investment incentives during 2000-2007

\begin{tabular}{lrcr}
\hline \hline (mil. CZK) & Realized FDI & Supported FDI & Paid incentives \\
\hline Středočeský & 157,888 & 61,475 & 761 \\
Jihočeský & 47,552 & 16,096 & 5 \\
Plzeňský & 32,756 & 15,879 & 18 \\
Karlovarský & 5,129 & 6,860 & 45 \\
Ústecký & 52,848 & 62,725 & 2,455 \\
Liberecký & 39,630 & 20,952 & 6 \\
Královehradecká & 17,474 & 13,408 & 11 \\
Pardubická & 18,798 & 21,550 & 11 \\
Vysočina & 57,035 & 27,844 & 55 \\
Jihomoravský & 45,374 & 26,544 & 540 \\
Olomoucký & 10,846 & 23,792 & 1,090 \\
Zlínsky & 31,627 & 10,616 & 25 \\
Moravskoslezský & 139,389 & 28,147 & 1,360 \\
\hline Czech Republic & 656,346 & 343,815 & 6,382 \\
\hline \hline
\end{tabular}

Note: Realized FDI is the actual FDI inflow during 2000-2007, supported FDI stands for the overall amount of planned investment (filled in the application for investment incentive) and paid incentives is the sum of total financial state subsidy during the period. The regions with the largest share of paid incentives are Středočeský region (TPCA investment - 593 mil. CZK), Ústecký region (Black \& Decker Overseas Holdings BV - 200 mil. CZK; IPS Alpha Technology - 140 mil. CZK; Eaton Industries - 130 mil. CZK), Olomoucký region (L.G. Phillips - 800 mil. CZK) and Moravskoslezský region (ASUS - 271,4 mil; Sungwoo Hitech - 150 mil. CZK). There was no individual company with more than 100 mil. CZK subsidy in the remaining regions. Prague is excluded. 
Table 9: Average FDI per capita inflow by district unemployment rate (euros)

\begin{tabular}{|c|c|c|c|c|}
\hline Year & $\overline{\mathrm{U}<\mathrm{U}_{-} \text {avg }}$ & $\overline{\mathrm{U}}$ _avg $<\mathrm{U}<1.25^{*} \mathrm{U}_{\text {avg }}$ & 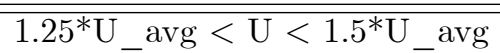 & $1.5^{*} \mathrm{U}_{-}$avg $<\mathrm{U}$ \\
\hline 2001 & $75 . \overline{5}$ & 125.8 & 64.6 & $\overline{43.5}$ \\
\hline 2002 & 66.6 & 148.0 & 17.9 & 61.2 \\
\hline 2003 & 78.4 & 138.1 & 42.1 & -35.1 \\
\hline 2004 & 61.7 & 69.3 & -37.7 & -82.4 \\
\hline 2005 & 123.1 & 47.9 & -87.6 & 162.4 \\
\hline 2006 & 117.8 & 90.6 & -98.6 & 398.6 \\
\hline
\end{tabular}

Note: For the calculation of average FDI per capita inflow the three years following the year pivotal for eligibility decision were considered. According to a change in scheme design, for the year 2006 an alternative grouping is used as $1.25^{*} \mathrm{U}_{-}$avg is replaced by $1.2 * \mathrm{U}_{-}$avg. Prague, Brno and Ostrava are excluded as FDI flows to metropolitan areas are specific and contain distortions (privatization of banks in the case of Prague, and larger concentration of service industry as compared with the rest of the Czech Republic). 
Table 10: Pooled OLS estimation: explaining FDI inflow by observables

\begin{tabular}{|c|c|c|c|c|c|c|}
\hline & coef. & st.err. & coef. & std.err. & coef. & std.err. \\
\hline & \multicolumn{2}{|c|}{ 1998-2007 } & \multicolumn{2}{|c|}{ 1998-2002 } & \multicolumn{2}{|c|}{ 2003-2007 } \\
\hline SECONDARY & 2.18 & $(6.00)$ & 0.01 & $(3.34)$ & 6.08 & $\begin{array}{l}(11.63) \\
\text { (1) }\end{array}$ \\
\hline TERCIARY & 12.34 & $(8.82)$ & $24.51^{* *}$ & $(9.28)$ & -4.26 & (14.44) \\
\hline MANUF & 1.95 & $(2.31)$ & 2.65 & $(3.07)$ & 0.87 & $(3.76)$ \\
\hline AGRI & 1.24 & $(0.94)$ & 0.55 & $(1.32)$ & 1.49 & $(1.15)$ \\
\hline HIGHWAY & 55.69 & $(52.81)$ & 23.00 & $(33.86)$ & 79.58 & $(93.40)$ \\
\hline EU15 & 62.29 & $(42.82)$ & 29.11 & $(37.57)$ & 99.81 & $(67.99)$ \\
\hline $\log ($ WAGE $)$ & $693.99^{*}$ & $(388.77)$ & $1174.53^{* * *}$ & $(346.23)$ & 183.45 & $(589.85)$ \\
\hline u_rate & -6.31 & $(9.29)$ & -7.30 & $(9.22)$ & -17.43 & $(12.74)$ \\
\hline v_rate & 8.71 & $(80.72)$ & -24.51 & $(51.38)$ & 49.39 & $(98.35)$ \\
\hline $\mathrm{uxv}$ & 0.24 & (11.61) & 5.12 & $(6.85)$ & -2.32 & $(15.43)$ \\
\hline LOW+MEDIUM & -2.36 & $(46.6)$ & 32.25 & $(46.57)$ & 39.31 & $(71.98)$ \\
\hline HIGH & 34.20 & $(73.15)$ & 12.56 & $(90.91)$ & 175.44 & $(123.21)$ \\
\hline $\mathrm{N}$ & 1480 & & 740 & & 740 & \\
\hline R-squared & 0.06 & & 0.16 & & 0.04 & \\
\hline
\end{tabular}

Note: Pooled linear regression explaining heterogeneity in FDI inflow per capita based on pooled data. The dependent variable is the forward-looking three-year average of FDI inflow. The following independent variables are time-invariant and characterize levels prior to the massive FDI inflow: variable SECONDARY indicates the share of population with secondary education and TERCIARY the share of college educated population; MANUF stands for the employment share in the manufacturing sector, AGRI indicates the share of agricultural land out of the total area of a district and HIGHWAY is a dummy indicating the presence of a state highway. Dummy EU15 indicates the border with Austria or Germany, u_rate is the unemployment rate and v_rate is the vacancy rate. Cities of Prague, Brno and Ostrava are excluded. Time trend coefficients and intercept are not displayed. Standard errors allow for intragroup correlation by clustering observations by district. Significance levels: *** $1 \%,{ }^{*} 5 \%, * 10 \%$. 
Table 11: Fixed-effects estimation: the role of incentives in FDI attraction

\begin{tabular}{|c|c|c|c|c|c|c|}
\hline & coef. & st.err. & coef. & std.err. & coef. & std.err. \\
\hline & \multicolumn{2}{|c|}{$1998-2007$} & \multicolumn{2}{|c|}{ 1998-2002 } & \multicolumn{2}{|c|}{$2003-2007$} \\
\hline u_rate & 6.60 & $(13.84)$ & -6.76 & $(12.39)$ & 10.53 & $(20.52)$ \\
\hline v_rate & -27.63 & (93.59) & -74.84 & $(92.79)$ & 1.29 & $(82.77)$ \\
\hline $\mathrm{u} \times \mathrm{v}$ & 5.81 & (10.93) & 10.93 & $(12.21)$ & 5.71 & (15.02) \\
\hline LOW+MEDIUM & 57.40 & $(52.42)$ & $77.213^{*}$ & $(45.93)$ & $165.16^{*}$ & $(98.91)$ \\
\hline HIGH & -27.44 & $(103.27)$ & -17.50 & $(116.85)$ & 137.83 & $(124.73)$ \\
\hline $\mathrm{N}$ & 1480 & & 740 & & 740 & \\
\hline R-sq. (between) & 0.07 & & 0.03 & & 0.04 & \\
\hline
\end{tabular}

Note: Fixed effects estimation explaining heterogeneity in FDI inflow per capita based on pooled data. The dependent variable is the forward-looking three-year average of FDI inflow. The following independent variables are time-invariant and characterize levels prior to the massive FDI inflow: variable SECONDARY indicates the share of population with secondary education and TERCIARY the share of college educated population; MANUF stands for the employment share in the manufacturing sector, AGRI indicates the share of agricultural land out of the total area of a district and HIGHWAY is a dummy indicating the presence of a state highway. Dummy EU15 indicates the border with Austria or Germany, u_rate is the unemployment rate and v_rate is the vacancy rate. Cities of Prague, Brno and Ostrava are excluded. Time trend coefficients and intercept are not displayed. Standard errors allow for intragroup correlation by clustering observations by district. Significance levels: ${ }^{* *} 1 \%,{ }^{* *} 5 \%,{ }^{*} 10 \%$. 


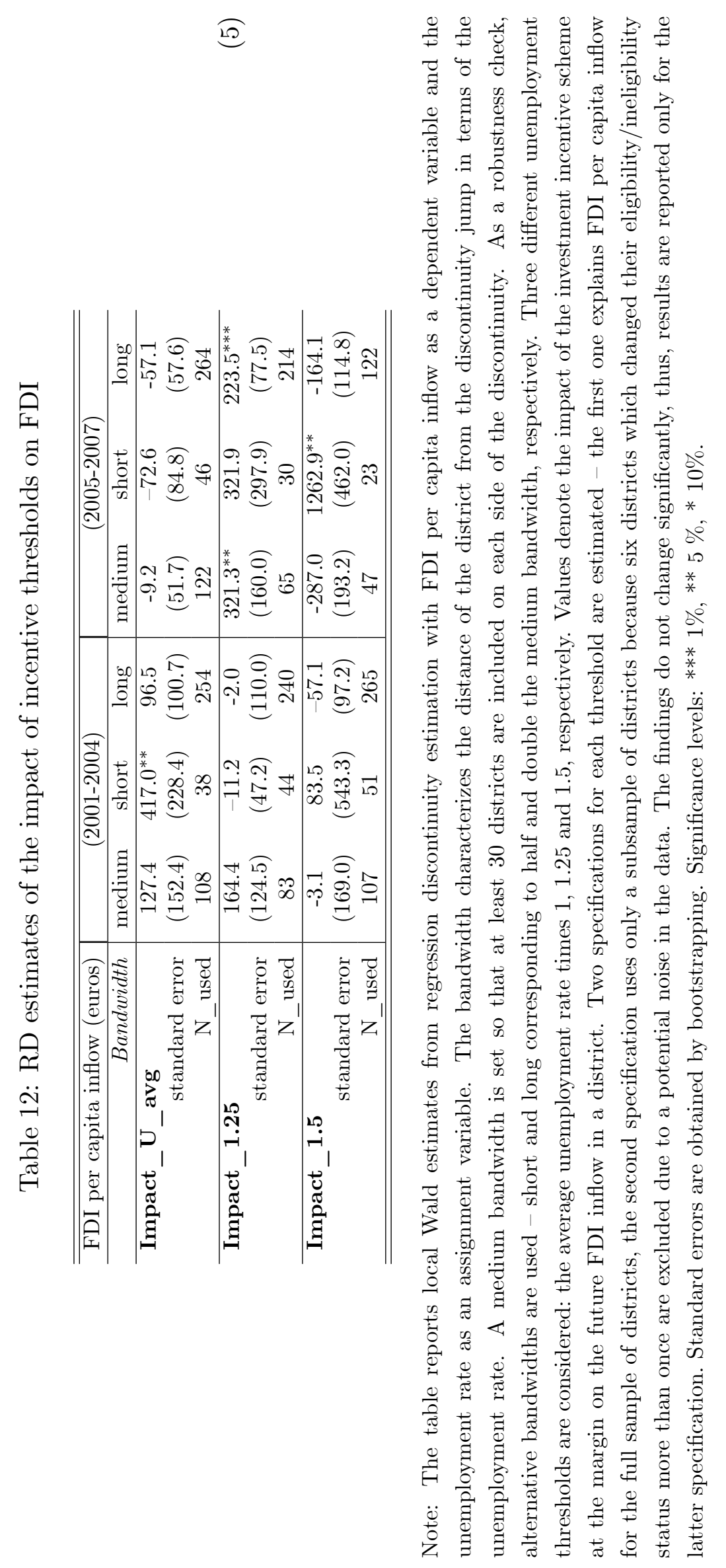


Working Paper Series

ISSN 1211-3298

Registration No. (Ministry of Culture): E 19443

(c) Marián Dinga, 2011

All rights reserved. No part of this publication may be reproduced, stored in a retrieval system or transmitted in any form or by any means, electronic, mechanical or photocopying, recording, or otherwise without the prior permission of the publisher.

Published by

Charles University in Prague, Center for Economic Research and Graduate Education (CERGE) and

Economics Institute ASCR, v. v. i. (EI)

CERGE-El, Politických vězňů 7, 11121 Prague 1, tel.: +420 224005 153, Czech Republic.

Printed by CERGE-EI, Prague

Subscription: CERGE-EI homepage: http://www.cerge-ei.cz

Phone: + 420224005153

Email: office@cerge-ei.cz

Web: http://www.cerge-ei.cz

Editor: Michal Kejak

Editorial board: Jan Kmenta, Randall Filer, Petr Zemčík

The paper is available online at http://www.cerge-ei.cz/publications/working_papers/.

ISBN 978-80-7343-239-3 (Univerzita Karlova. Centrum pro ekonomický výzkum a doktorské studium)

ISBN 978-80-7344-230-9 (Národohospodářský ústav AV ČR, v. v. i.) 
CERGE-EI

P.O.BOX 882

Politických vězňů 7

11121 Praha 1

Czech Republic http://www.cerge-ei.cz 